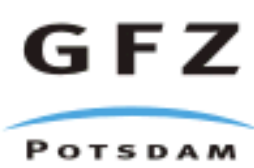

Originally published as:

Glodny, J., Kühn, A., Austrheim, H. (2008): Geochronology of fluid-induced eclogite and amphibolite facies metamorphic reactions in a subduction-collision sytem, Bergen Arcs, Norway. - Contributions to Mineralogy and Petrology, 156, 1, 27-48

DOI: 10.1007/s00410-007-0272-y. 


\title{
Geochronology of fluid induced eclogite and amphibolite facies metamorphic reactions in a subduction-collision system, Bergen Arcs, Norway
}

\author{
Johannes Glodny ${ }^{(1)}$, Alexander Kühn ${ }^{(2,3)}$ Håkon Austrheim ${ }^{(3)}$, \\ (1) GeoForschungsZentrum Potsdam, Telegrafenberg C2, 14473 Potsdam, Germany. \\ Corresponding author. email: glodnyj@gfz-potsdam.de. Tel.: ++493312881375 \\ (2) Institut für Geowissenschaften, Johannes Gutenberg-Universität, Becherweg 21, 55099 \\ Mainz, Germany
}

(3) PGP and Department of Earth Sciences, Postboks 1047, University of Oslo, N-0316 Oslo, Norway

\begin{abstract}
Rb}-\mathrm{Sr}$ multimineral isochron data for metamorphic veins allow to date separate increments of the mineral reaction history of polymetamorphic terranes. Granulite facies rocks of the Lindås nappe, Bergen Arcs, Norway, were subducted and exhumed during the Caledonian orogeny. The rocks show petrographic evidence for two distinct events of local fluid infiltration and vein formation, along fractures and shear zones. The first occurred at eclogite facies $\left(15-21 \mathrm{kbar}, 650-750{ }^{\circ} \mathrm{C}\right)$ and a later one at amphibolite facies conditions (8$10 \mathrm{kbar}, 600^{\circ} \mathrm{C}$ ). The presence of fluids enabled local metamorphic equilibration only near fluid pathways. In fluid-absent domains, preexisting assemblages were metastably preserved. This resulted in a heterogeneity of metamorphic signatures on $\mathrm{m}$ - to $\mu \mathrm{m}$-scales. Well-preserved granulite facies rocks preserve their Proterozoic $\mathrm{Rb}-\mathrm{Sr}$ mineral ages, as does the U-Pb system of zircon in most lithologies. Six $\mathrm{Rb} / \mathrm{Sr}$ multimineral isochron ages for eclogite facies veins and their immediate wallrocks date the fluid-induced eclogitization at $429.9 \pm 3.5 \mathrm{Ma}(2 \sigma$, weighted average, MSWD $=0.39)$. An eclogite facies vein has yield metamorphic zircon with concordant U-Pb ages of $429 \pm 3 \mathrm{Ma}$, identical to the U-Pb age of $427.4 \pm 0.9 \mathrm{Ma}$ for zircon xenocrysts in an amphibolite facies vein. Seven $\mathrm{Rb} / \mathrm{Sr}$ mineral isochron ages date amphibolite-facies fluid infiltration at 414.2 $\pm 2.8 \mathrm{Ma}(\mathrm{MSWD}=1.5$ ), an age value testifying to residence of the rocks in the deep orogenic crust at temperatures $>600^{\circ} \mathrm{C}$ for nearly $15 \mathrm{Ma}$. The new data show that $\mathrm{Rb}-\mathrm{Sr}$ mineral isochron ages effectively date fluid-induced (re)crystallization events rather than stages of cooling. The direct link between isotopic ages and distinct petrographic equilibrium assemblages aids to constrain the evolution of rocks in the P-T-reaction-time space, which is essential for understanding exhumation histories and the internal dynamics of orogens in general.
\end{abstract}

Keywords: eclogite, amphibolite, fluid-rock interaction, $\mathrm{Rb}-\mathrm{Sr}, \mathrm{U}-\mathrm{Pb}$, Norway

\section{Introduction}

The architecture of the Scandinavian Caledonides is largely the result of continent-continent collision between Baltica-Avalonia and Laurentia, and of subsequent extension of the orogen in the Late Silurian to Middle Devonian (Roberts and Gee 1985, Torsvik et al. 1996, Fossen 2000). Western Norway offers surface exposure of a fragmented but complete crustal section of the collapsed orogen, including rocks that have been subducted and exhumed from depths of more than $100 \mathrm{~km}$. The Bergen Arcs high pressure (HP) rocks form, together with the Western Gneiss Region (WGR), one of the largest HP- to UHP provinces in the world. The Bergen Arcs HP rocks are famous for their preservation of km-scale coherent eclogite 
facies deformation patterns, and for recording progressive eclogitization at depth (Austrheim 1987, Austrheim and Boundy 1994, Jolivet et al. 2005). They offer an unique opportunity to study metamorphic and tectonic processes in the eclogite facies root zones of collisional orogenic belts. Local exhumation-related tectonic overprint and associated retrograde mineral reactions in these rocks potentially provide insight on how HP rocks approach the upper crust.

To explore all the information contained in HP rocks on the internal dynamics of collisional orogens at depth, geochronological data is of key importance. Ideally, age data should be unequivocally linked to specific processes in a rocks' history, for which indications for pressure, temperature and the deformation regime are available. To firmly establish the timing of a distinct metamorphic event, several independent and consistent age estimates are desirable, either from different isotope systems or from a variety of samples. If several subsequent stages of overprint during subduction and exhumation can be distinguished and accurately dated, a rock volume may serve as a 'track recorder' on its way through an evolving orogen.

The Lindås nappe of the Bergen Arcs, W Norway (Fig. 1) is composed of rocks of the anorthosite-mangerite-charnockite-granite suite (Kolderup and Kolderup 1940). Magmatic crystallization ages range from $\sim 1240 \mathrm{Ma}$ to $951 \pm 2 \mathrm{Ma}$ (Bingen et al. 2001). The complex witnessed diverse metamorphic imprints. The rocks were entirely recrystallized at granulite facies conditions during the Grenvillian (Sveconorwegian) orogeny (at around $930 \mathrm{Ma}$, Bingen et al. 2001). Protracted high-temperature conditions are indicated by Sm-Nd and RbSr mineral ages between $929 \pm 9$ and $835 \pm 7$ Ma (Cohen et al. 1988, Burton et al. 1995, Kühn et al 2000).

During the Caledonian orogeny, the granulite facies rocks were partially transformed to eclogite. Age data for this eclogitization event are crucial for reconstruction of the Caledonian orogeny. Numerous attempts have been made at isotopic dating of the eclogite metamorphism. Published ${ }^{40} \mathrm{Ar}-{ }^{39} \mathrm{Ar}, \mathrm{Rb}-\mathrm{Sr}, \mathrm{Sm}-\mathrm{Nd}$, and $\mathrm{U}-\mathrm{Pb}$ based age results, employing various mineral systems, scatter between roughly 460 and $420 \mathrm{Ma}$ (Cohen et al. 1988, Bingen et al. 2001, Bingen et al. 2004; Boundy et al. 1996, 1997a, 1997b). Inconsistency between the existing age data appears to relate to isotopic disequilibria in and among minerals of some of the studied eclogites. Such disequilibrium problems are common in eclogite geochronology, and often very difficult to recognize. They have manifold reasons, including isotopic inheritance (cf. Villa 2004 and references therein), incorporation of excess Ar into HP minerals (Scaillet 1998), persistence of zircon cores through metamorphism (Bingen et al. 2004), limited isotopic homogenization during metamorphic mineral reactions (Thöni and Jagoutz 1992, Romer and Siegesmund 2003), or incipient retrograde mineral reactions (Di Vincenzo and Palmeri 2001).

Post-eclogite-facies exhumation of the Lindås nappe was accompanied by local amphibolite facies overprint of granulites and eclogites (Austrheim et al. 1990, Boundy et al. 1996). Published $\mathrm{Rb}-\mathrm{Sr}$ and ${ }^{40} \mathrm{Ar} /{ }^{39} \mathrm{Ar}$ age estimates for this overprint (Austrheim et al. 1990; Boundy et al 1996) are inconclusive as they cover a wide range of ages, between $>455 \mathrm{Ma}$ and $409 \pm$ $8 \mathrm{Ma}$. Based on age data for granitoid dykes, Kühn et al. (2002) bracketed the amphibolite facies overprint to between $\sim 425$ and $409 \pm 8 \mathrm{Ma}$.

This study re-addresses the geochronology of eclogite facies and amphibolite facies overprints in the Lindås nappe. Recent studies have shown that multimineral $\mathrm{Rb}-\mathrm{Sr}$ isochron data yield precise and accurate ages for eclogite facies metamorphic reactions, provided that a) eclogite facies equilibrium assemblages are analyzed, and b) that demonstrably no posteclogitic diffusional intermineral isotope redistribution occurred (Glodny et al. 2002, Glodny et al. 2005). The Bergen Arcs eclogites contain numerous eclogite facies quartz-phengitekyanite-omphacite veins. Such veins are commonly formed during subduction, at progradeto peak stages of the eclogitization process (Becker et al. 1999, Widmer and Thompson 2001, Glodny et al. 2005). For a number of vein occurrences worldwide, it has been shown that fluids were in isotopic equilibrium with their host rocks (e.g., Nadeau et al. 1993, Glodny et al. 2005). We therefore focus $\mathrm{Rb}-\mathrm{Sr}$ work on vein assemblages and assemblages in the immediate wallrocks, because achievement of inter-mineral $\mathrm{Sr}$ isotopic equilibrium is likely in these lithologies. We also surveyed a number of veins for fluid-precipitated zircon suitable for 
$\mathrm{U}-\mathrm{Pb}$ dating of fluid activity. Amphibolite facies recrystallization is most complete in the vicinity of amphibolite facies fluid pathways. Some of these pathways are filled with fluidprecipitated veins. We date amphibolite facies fluid activity using Rb-Sr, Sm-Nd and U-Pb mineral data from these veins and their wallrocks. Isotope data are complemented by an evaluation of the P,T conditions recorded in the dated rocks. Our results put new constraints on the much-discussed Caledonian metamorphic and tectonic history of the Lindås nappe.

\section{Geological setting}

During the Caledonian orogeny, the western margin of Baltica was subducted below Laurentia. Subduction and subsequent collision created high-pressure metamorphic rocks that were subsequently exhumed. During exhumation, high-pressure rocks of the Bergen Arcs were thrusted towards southeast, onto the Baltica margin (e.g., Roberts and Gee 1985). The Bergen Arcs (Fig. 1) form an arcuate structure of Caledonian nappes, centered around the city of Bergen. A main constituent is the Lindås nappe, characterized by granulite facies anorthositic rocks with a HP metamorphic imprint. The Lindås nappe tectonically rests upon the Hardangerfjord nappe (Ragnhildstveit and Helliksen 1997). The Hardangerfjord nappe is made up of Late Ordovician to Early Silurian (Llandovery) metasediments of mainly oceanic affinity (Kolderup and Kolderup 1940, Dunning and Petersen 1988). It is intruded by the syntectonic Krossnes granite, located about $20 \mathrm{~km}$ south of Bergen and dated at $430 \pm 6 \mathrm{Ma}$ (Rb-Sr whole rock isochron; Fossen and Austrheim 1988). The W-dipping Bergen Arcs shear zone forms the eastern limit of the Bergen Arcs nappe stack. To the east, in the footwall of this fault, basement rocks of the Western Gneiss Region are located, which similar to the Lindås nappe show a Caledonian HP metamorphic overprint. Subduction-related metamorphic signatures are thus present in the regionally lowermost and uppermost tectonostratigraphic positions (cf. Boundy et al. 1996, 1997a and references therein). The Lindås nappe is unconformably overlain only by Middle Devonian continental-clastic sediments of the Fensfjorden basin (e.g., Wennberg and Milnes 1994).

\section{Field aspects of metamorphism}

The Lindås nappe is interpreted as reworked continental lower crust (Austrheim and Griffin 1985). Caledonian overprint is manifested in partial eclogitization of the preexisting granulites, followed by local amphibolite facies shearing and retrogression. Local greenschist facies overprint is present as well (Austrheim and Griffin 1985, Austrheim 1987, Austrheim and Mørk 1988). Eclogitization is regionally unevenly distributed in the Lindås nappe. The highest degree of eclogitization is seen in the NW part of Holsnøy island, where eclogite accounts for more than $50 \%$ of the total rock volume (Fig. 1), and where the highest Caledonian $\mathrm{P}, \mathrm{T}$ conditions are recorded. Maximum metamorphic $\mathrm{P}, \mathrm{T}$ conditions appear to decrease towards $E$ in the Lindås nappe. Jadeite content in omphacite is lower on Radøy island than on Holsnøy (Fig. 1). In the eastern part of the Lindås nappe, eclogites are missing (cf. Kühn 2002). Eclogitization is clearly related to fluid influx from external sources into the anorthositic unit. Granulite is converted to eclogite around fractures, which are either sealed by quartz, or filled with quartz-phengite-kyanite-clinozoisite-omphacite assemblages (Fig. 2a; Austrheim and Mørk 1988). Omphacite and clinozoisite crystals in eclogite facies veins are locally idiomorphic (Fig. 2f), suggesting growth in an open space filled with fluid. Minerals of the veins show eclogite facies textural equilibrium. They are commonly coarsegrained, with omphacite prisms or white mica 'books' up to several $\mathrm{cm}$ in size. Geometry of eclogite facies veins varies. Some veins developed on a network of fracture planes (e.g., Fig. 2a). Others appear to take the place of former fluid channels and are disc-shaped in cross section (Fig. 2c). Eclogite facies deformation is spatially linked to zones of fluid infiltration (Fig. 2a) and triggers further eclogitization (Austrheim and Griffin 1985, Austrheim 1987, 1998). Obviously the granulite-to-eclogite reaction progress is limited by the availability of 
hydrous fluid. In absence of fluid as a reactant, the granulite is metastably preserved, an inference that can be generalized (e.g., Bjørnerud et al. 2002).

Field evidence shows that local amphibolitization postdates the partial eclogitization (e.g., Fig. 2c-e; Andersen et al. 1991a, Schneider et al. 2006), and that amphibolitization is similarly fluid-limited. Amphibolitization of both eclogites and granulites occurs in $\mathrm{cm}$ - to $\mathrm{m}$ wide aureolas around amphibolite facies fluid pathways, which are sealed with quartzplagioclase-dominated assemblages (Fig. 2e). In addition, amphibolitization occurs in $\mathrm{cm}$ - to $\mathrm{m}$-sized patches (Fig. 2c). These patches are most likely related to local fluid access through faults and cracks. A slight, arrested amphibolite facies overprint is present in most rocks of the Lindås nappe. In the eclogites this is evident from formation of reaction rims around garnet and from symplectitic breakdown of omphacite, starting from cracks and grain boundaries (Fig. 2d). In granulites, incipient biotite formation at the expense of pyroxenes is commonly observed (Austrheim et al. 1990). It appears that on a microscopic, sub-grain scale, most rocks of the Lindås nappe show disequilibrium textures, recording more than one event of the metamorphic history.

\section{Petrography and sampling}

Pristine granulites of the Lindås nappe typically consist of plagioclase, \pm K-feldspar, quartz, clinopyroxene, orthopyroxene, garnet-(I), dark brown amphibole, \pm scapolite, and apatite. Whole rock chemistry is variable. Mafic, K-poor, anorthosite-gabbro-like compositions dominate in the most intensely eclogitized NW part of Holsnøy, while elsewhere charnockiticmangeritic compositions predominate (Austrheim 1990). In places, granulite facies ultramafic, olivine-rich rocks occur as $\mathrm{m}$-scale lenses. They preserve their granulite facies mineralogy, even in eclogitized matrix (Kühn et al. 2000, Camacho et al. 2005). We sampled pristine quartz mangerite (Taulsvågen, Radøy) for zircon U-Pb analysis (Samples HA693, HA696; see Appendix for detailed description).

Full eclogitization of granulite is achieved only immediately along zones of fluid infiltration and in related shear zones. Distal to these zones, eclogitization is incomplete. Petrographically relic-free eclogitic assemblages are also present within the eclogite facies veins (see above). Unaltered eclogite presents a light green color. Typical eclogite assemblages are omphacite, eclogitic garnet, phengite, epidote group phases, kyanite, quartz, rutile, apatite, \pm paragonite \pm amphibole \pm feldspar phases \pm calcite/dolomite. Preservation of eclogite from amphibolite facies retrogression is best in quartz-kyanite-rich varieties, i.e., in transition zones between eclogitic veins and their wallrocks. For $\mathrm{Rb}-\mathrm{Sr}$ isotopic dating of eclogitization we selected six samples of eclogitic veins and wallrock (samples 50-00V; 50-00E; ABJ; HUS2; 78-99; 77-99; see Appendix for details). Not all of the veins include the subassemblage garnet+omphacite, but all of them at least coexist with garnet+omphacite in their immediate wallrock, testifying to their formation at eclogite facies conditions. Characteristic sample sizes were $<200 \mathrm{~g}$, to minimize the risk of intra-sample Srisotopic heterogeneities. For evaluating the effect of incipient amphibolite facies overprint on $\mathrm{Rb}-\mathrm{Sr}$ mineral systematics we also analyzed two samples of partly amphibolitized vein material (samples STRO1, ADNA, see Appendix). In a search for possible eclogite facies, fluid-precipitated zircon in eclogitic veins we only detected zircon in 4 out of $\sim 10$ vein samples. Only vein samples ABJ and ADNA produced enough zircon for U-Pb analysis.

With increasing degree of amphibolitization, the light green color of eclogite gradually changes to dark green. This is mainly due to growth of calcic amphibole, biotite and chlorite at the expense of omphacite, phengite and $\mathrm{Na}-\mathrm{Ca}$-amphibole. Even minute amphibolitization is easily recognized, because biotite forms conspicious small epitactic overgrowths on phengite. Amphibolitization reactions further include growth of plagioclase and epidote, conversion of rutile to sphene \pm ilmenite, and conversion of high-Si phengite-(I) to low-Si phengite-(II). Locally, kyanite and garnet are stable during amphibolitization. Abundance of hydrous phases in amphibolite assemblages points to the importance of fluid infiltration. Consequently, relic-free amphibolite facies rocks are present in the field either in amphibolite facies veins and shear zones, or in the immediate wallrock of such veins. For Rb-Sr work we 
selected two amphibolite facies vein samples (HOL4, 81-99), one vein wallrock (HU11b), two amphibolite facies gneisses (SJU1, SJU2), and two amphibolitized former eclogites without indications for amphibolite facies deformation (static amphibolitization; AB1, HUS1a). The vein sample HOL 4 produced some zircon which we analyzed for U-Pb. Presence of several REE-rich, amphibolite facies phases in the statically amphibolitized sample AB1 (Fig. 2c) prompted us to analyze this sample for Sm-Nd mineral systematics.

\section{Analytical procedures}

For $\mathrm{Rb} / \mathrm{Sr}$ and $\mathrm{Sm} / \mathrm{Nd}$ isotope work, mineral concentrates of the white micas, omphacite, garnet, apatite, epidote/zoisite, feldspar, amphibole, sphene, and biotite were produced. In general, care was taken to select material without any reaction rims or alteration. White mica sieve fractions were ground in ethanol in an agate mortar and then sieved in ethanol in order to obtain inclusion-free separates. Secondary (Fe, Mn)-hydroxides on some mineral separates were removed with a $5 \%$ aqueous solution of oxalic acid. All concentrates were purified by hand-picking under the binocular microscope. Whole rock powders were prepared in an agate mill.

Samples were analyzed for $\mathrm{Rb}, \mathrm{Sr}, \mathrm{Sm}$, and $\mathrm{Nd}$ contents by isotope dilution. They were weighed into Savillex® screw-top containers, spiked with mixed ${ }^{87} \mathrm{Rb},{ }^{84} \mathrm{Sr}\left({ }^{149} \mathrm{Sm},{ }^{150} \mathrm{Nd}\right)$ spike solutions, and dissolved in a mixture of $\mathrm{HF}$ and $\mathrm{HNO}_{3}$. Solutions were processed by standard cation-exchange techniques. Determinations of $\mathrm{Sr}$ isotope ratios were carried out on a VG Sector 54 multicollector thermal ionisation mass spectrometer (GFZ Potsdam) in dynamic mode. The value obtained for ${ }^{87} \mathrm{Sr} /{ }^{86} \mathrm{Sr}$ of the NBS standard SRM 987 during the main period of analytical work were $0.710263 \pm 0.000010(n=16)$. Rb analyses were done on either a VG Isomass 54 single collector TIMS instrument or on a VG Sector 54, both at GFZ Postdam. Observed Rb isotopic ratios were corrected for $0.25 \%$ per a.m.u. mass fractionation. Total procedural blanks were consistently below $0.15 \mathrm{ng}$ for both $\mathrm{Rb}$ and $\mathrm{Sr}$. Due to highly variable blank values, no blank correction was applied. Standard errors, as derived from replicate analyses of spiked white mica samples, of $+/-0.004 \%$ for ${ }^{87} \mathrm{Sr} /{ }^{86} \mathrm{Sr}$ ratios and of $+/-1.5 \%$ for $\mathrm{Rb} / \mathrm{Sr}$ ratios were applied in isochron age calculations (cf. Kullerud 1991 ) except for the rare cases in which determined analytical uncertainties were bigger than these values. Uncertainties of isotope and age data are quoted at $2 \sigma$ throughout this work. The program ISOPLOT/EX 2.06 (Ludwig, 1999) was used to calculate regression lines.

$\mathrm{Sm}, \mathrm{Nd}$ isotope analyses were carried out on a Finnigan MAT 262 mass spectrometer at the GFZ Postdam. Nd was analyzed in dynamic, $\mathrm{Sm}$ in static mode. For age calculation, standard errors of $\pm 0.003 \%$ for ${ }^{143} \mathrm{Nd} /{ }^{144} \mathrm{Nd}$ ratios and $\pm 0.5 \%$ for ${ }^{147} \mathrm{Sm} /{ }^{144} \mathrm{Nd}$ ratios were assigned to the results.

For U-Pb analysis, zircon and feldspar grains were hand-picked under the binocular microscope. Zircon was then cleaned in diluted $\mathrm{HNO}_{3}$ and ultraclean $\mathrm{H}_{2} \mathrm{O}$. Some zircon fractions were also leached in hot Aqua Regia for $12 \mathrm{~h}$ to remove loosely bound $\mathrm{U}$ and $\mathrm{Pb}$ from possible pores and metamict zones. Zircon samples were put in Savillex ${ }^{\mathrm{TM}}$ teflon capsules together with a ${ }^{205} \mathrm{~Pb}-{ }^{235} \mathrm{U}$ mixed isotopic tracer and a mixture of concentrated HF$\mathrm{HNO}_{3}$ acids, then placed in a teflon insert into a Parr ${ }^{\mathrm{TM}}$ bomb, and heated for three days to $230^{\circ} \mathrm{C}$ to achieve complete digestion. Dissolution of the low-U zircon from sample HOL4 (see below) required heating to $250^{\circ} \mathrm{C}$ for up to 8 weeks. Standard ion exchange methods were used for chemical separation of $\mathrm{Pb}$ and $\mathrm{U}$. Separates were loaded on single Re filaments. $U$ and $\mathrm{Pb}$ isotopic analyses were conducted using a Finnigan MAT-262 at the GFZ Postdam. The $2 \sigma$ reproducibility of the NBS SRM- $981 \mathrm{~Pb}$ isotopic standard is better than $0.1 \%$ for the ${ }^{206} \mathrm{~Pb} /{ }^{204} \mathrm{~Pb}$ and ${ }^{207} \mathrm{~Pb} /{ }^{204} \mathrm{~Pb}$ ratios, and corresponding uncertainties in ${ }^{207} \mathrm{~Pb} /{ }^{206} \mathrm{~Pb}$ ratios are $<0.06 \%$. Laboratory blanks for the above procedure are $<25 \mathrm{pg}$ for $\mathrm{Pb}$ and $<3 \mathrm{pg}$ for $\mathrm{U}$. Measured isotopic ratios were corrected by $0.11+/-0.05 \%(2 \sigma) /$ a.m.u. mass fractionation. Data reduction and age calculation was performed using the programs PBDAT (Ludwig, 1993) and Isoplot/Ex (Ludwig, 1999).

Quantitative mineral analyses used for thermobarometry were performed on a CAMECA Camebax Microprobe at the Geological Museum at the University of Oslo. Natural and 
synthetic phases were used for calibration. Mineral analyses were performed using an accelerating voltage of $15 \mathrm{kV}$, a beam current of $10 \mathrm{nA}$ and a defocused electron beam. Data reduction was done using the CAMECA PAP software.

\section{P-T estimates for Caledonian metamorphic events}

\section{Eclogite facies}

For eclogite facies metamorphism, conditions around 650 to $700^{\circ} \mathrm{C}$ and $15 \mathrm{kbar}$ are derived (Fig. 3a). Thermometry is based on the Mg-Fe exchange between coexisting garnet and omphacite using the calibrations from Powell (1985), Krogh (1988) and Krogh Ravna (2000). Pressure estimates rely on Jd-content in clinopyroxene (Holland 1980, 1983) and the garnetphengite-omphacite barometer (Waters and Martin 1993)..In eclogites from Holsnøy, Si in phengite varies between 3.15 and 3.3 apfu (Supplementary Table.1; Raimbourg et al. 2007). This indicates minimum pressures in the range of $15 \mathrm{kbar}$ at $700^{\circ} \mathrm{C}$ (Fig. 3a; Si-in-phengite barometer of Massone and Schreyer (1989), $\mathrm{Si}_{\text {Phe }}=3.2$ )

A survey of existing $\mathrm{P}, \mathrm{T}$ data for the Bergen Arcs eclogites reveals full consistency between existing temperature estimates at $\sim 700^{\circ} \mathrm{C}$. (Supplementary Table 2). A pressure of $15 \mathrm{kbar}$ appears to be a robust minimum pressure estimate. Jamtveit et al. (1990) argued, from the coexistence of cpx, pg, ky and qtz, that $\sim 21$ kbar denotes the maximum recorded pressure in the Bergen Arcs eclogites.

\section{Amphibolite facies}

Amphibolite facies mineral associations developed in Bergen Arcs lithologies are not favourable for precise estimates on $\mathrm{P}, \mathrm{T}$ conditions. Yet, composition of phengitic white mica and amphibole vary systematically between amphibolite facies and eclogite facies rocks, which provides hints to amphibolite facies recrystallization conditions. Si in phengite of amphibolite facies rocks is between 3.05 and 3.09 (compared to 3.15-3.3 in eclogites; see Supplementary Table 1; Raimbourg et al. 2007). This corresponds to minimum pressure between 6 and $8 \mathrm{kbar}$ at estimated $600^{\circ} \mathrm{C}$ (cf. Massonne and Schreyer 1989).

As to amphibole mineral chemistry, amphibole characterized by high $\mathrm{Na}$ in the M4 position $(>0.5 \mathrm{pfu})$ and in the A-position ( $\geq 0.75 \mathrm{pfu})$ is restricted to eclogites. In the amphibolites, $\mathrm{Na}(\mathrm{A})$ is generally lower $(<0.5 \mathrm{pfu})$ but equally high in the M4-position (data of the authors, to be presented elsewhere). These changes and the generally higher $\mathrm{Al}^{\mathrm{IV}}$ content in the amphiboles from the eclogites indicate significantly lower $\mathrm{P}$ and/or $\mathrm{T}$ for amphibolite facies recrystallization compared to eclogite metamorphism.

In amphibolite facies chlorite-amphibole-plagioclase coronas, tschermakitic and Mghornblende are in textural equilibrium with plagioclase. This assemblage corresponds to temperatures between 560 and $600^{\circ} \mathrm{C}$ ( $\mathrm{Hbl}-\mathrm{Pl}$ thermometer of Blundy and Holland 1990). The calibrations of this thermometer by Plyusnina (1982) and Spear (1980) yield temperatures between 550 and $600^{\circ} \mathrm{C}$; the Plyusnina calibration indicates a metamorphic pressure in excess of $8 \mathrm{kbar}$ (unpublished data of the authors).

A common feature in amphibolitized eclogites is the partial breakdown of kyanite enclosed in plagioclase to zoisite + margarite. This reaction can be modelled in the system $\mathrm{CaO}-\mathrm{Al}_{2} \mathrm{O}_{3^{-}}$ $\mathrm{SiO}_{2}-\mathrm{H}_{2} \mathrm{O}(\mathrm{CASH})$ using the phases margarite, zoisite, kyanite and anorthite. Based on equilibrium between the phases zoisite, margarite, quartz and plagioclase an invariant point I [Zo, $\mathrm{Ky}, \mathrm{Mrg}, \mathrm{Qtz}, \mathrm{H}_{2} \mathrm{O}$ ] at $\sim 8 \mathrm{kbar}, ~ 660^{\circ} \mathrm{C}$ is calculated in a petrogenetic grid (constructed using TWEEQU (Berman 1991); Fig. 3b).

Summarizing the above results, we adopt $8-10 \mathrm{kbar}, 600^{\circ} \mathrm{C}$ as likely conditions for the amphibolite facies fluid-rock interaction episode.

\section{Results: Isotope data}


Two well-preserved granulite facies quartz mangerite samples from Taulsvågen, Radøy, produced large zircon crystals with anhedral shapes and characteristically corroded or rounded surfaces. One zircon fraction yields U-Pb data concordant at $\sim 980 \mathrm{Ma}$. Together with the other fraction, a discordia line is defined with an upper intercept at $978.8 \pm 5.7 \mathrm{Ma}$ (Fig. 4) and a poorly defined lower intercept at $222 \pm 240$ Ma (Fig. 4).

\section{Eclogite facies rocks}

All analyzed eclogite facies veins and vein wallrocks yielded valid $\mathrm{Rb}-\mathrm{Sr}$ mineral isochron ages, numerically between $422 \pm 23 \mathrm{Ma}$ and $431.0 \pm 3.9 \mathrm{Ma}$ (Tab. 1 ; results for samples $\mathrm{ABJ}$ and HUS2 in Fig. 5). With the exception of sample ABJ, eclogite facies white mica is characterized by uncommonly low ${ }^{87} \mathrm{Rb} /{ }^{86} \mathrm{Sr}$ ratios, typically around 0.1 , resulting in enhanced age uncertainties (Tab. 1). The six $\mathrm{Rb} / \mathrm{Sr}$ multimineral isochron ages are identical within limits of error. The weighted average of the ages is $429.9 \pm 3.5 \mathrm{Ma}$ (95\% conf., MSWD $=0.39$ ).

Two samples of eclogite facies vein mineralizations present indications for incipient amphibolitization (e.g., growth of symplectite rims on omphacite, Fig. 2d; samples STRO1, ADNA; Tab. 1). These rocks consistently show Sr-isotopic inter-mineral disequilibria, which renders their $\mathrm{Rb}-\mathrm{Sr}$ isotope datasets geochronologically meaningless.

Zircon was recovered from two eclogite facies veins. U-Pb analysis of three zircon fractions from sample ABJ (Fig. 2c; Supplementary Table 3) yields a discordia with an upper intercept age of $952 \pm 19 \mathrm{Ma}$ and a lower intercept at $588 \pm 38 \mathrm{Ma}$ (Fig. 4). U-Pb analysis of 5 zircon fractions from vein sample ADNA (Fig. 2f) produced a cluster of concordant data at $429 \pm 3$ Ma (Fig. 6).

\section{Amphibolite facies rocks}

Amphibolite facies veins (samples HOL4, 81-99), their immediate wallrocks (sample HU11b, Fig. 2e), and rocks deformed at amphibolite facies conditions (samples SJU1, SJU2) provide $\mathrm{Rb}-\mathrm{Sr}$ mineral data indicating complete isotopic equilibration at around $414 \mathrm{Ma}$ (Tab. 1; data of HU11b and HOL4 shown in Fig. 5). One of the statically amphibolitized rocks (sample ABJ) shows slight disequilibria among low-Rb/Sr phases (MSWD of data regression $=9.4$ ), while the two others (samples HU11b and HUS 1a) yield valid isochrons. Taken together, the seven $\mathrm{Rb} / \mathrm{Sr}$ multimineral isochron ages for amphibolite facies assemblages are identical within limits of error, with a weighted average of ages of $414.2 \pm 2.8 \mathrm{Ma}$ ( $95 \%$ conf., MSWD = 1.5).

Sm-Nd mineral data for the statically amphibolitized sample AB1 (Fig. 2c) define a Sm-Nd isochron, corresponding to an age of $422 \pm 10 \mathrm{Ma}$ (MSWD = 1.2; Fig. 5; Supplementary Table 4)

From an amphibolite facies vein (sample HOL4; field aspect similar to Fig. 2e) we recovered zircon. U-Pb analysis revealed that this zircon has very low $U$ contents of $\sim 4 \mathrm{ppm}$, and radiogenic lead at the ppb level. ${ }^{206} \mathrm{~Pb} /{ }^{204} \mathrm{~Pb}$ ratios of the analyzed $\mathrm{Pb}$ are between 22.3 and 290, with the lowest value for a zircon fraction particularly rich in inclusions (Supplementary Table 5). Due to adverse counting statistics, geochronological evaluation of the ${ }^{235} \mathrm{U}-{ }^{207} \mathrm{~Pb}$ decay system was not feasible. Exploring the data for the ${ }^{238} \mathrm{U}-{ }^{206} \mathrm{~Pb}$ decay system only, we obtained an isochron age of $427.4 \pm 0.9 \mathrm{Ma}$ for the zircon fractions (MSWD $=0.95, \mathrm{n}=5$; Fig. 6).

\section{Discussion}

\section{Geochronology of granulite facies rocks}

$\mathrm{U}-\mathrm{Pb}$ data for zircon from pristine granulite facies quartz mangerite samples from Taulsvågen, Radøy, define a discordia line with an upper intercept at $978.8 \pm 5.7 \mathrm{Ma}$ (Fig. 4). The age of granulite facies metamorphism in the area is well defined by U-Pb ID-TIMS data, at $933 \pm 2 \mathrm{Ma}$ and $929 \pm 1 \mathrm{Ma}$, respectively (Bingen et al. 2001). We therefore interpret the age of $978.8 \pm 5.7 \mathrm{Ma}$ as crystallization age of the magmatic precursor of the granulite. This 
age value falls in between the existing two clusters of intrusion ages for Lindås nappe igneous protoliths $(\sim 1240 \mathrm{Ma}$ and near $951 \pm 2 \mathrm{Ma}$, Bingen et al. 2001). It appears that emplacement of the protoliths has been a protracted process, with several distinct magmatic episodes.

\section{Timing and mode of the eclogite facies overprint}

\section{Inherited zircon in an eclogite facies vein}

The eclogite facies vein sample ABJ (Fig. 2c) included zircon with mostly anhedral to rounded shapes, analyzed in an attempt to date eclogite facies vein precipitation. Crystal sizes reach up to $400 \mu \mathrm{m}$. Three zircon multigrain fractions define a discordia line with an upper intercept age at $952 \pm 19 \mathrm{Ma}$ and a lower intercept age of $588 \pm 38 \mathrm{Ma}$ (Fig. 4). From these data it is clear that this eclogitic vein carries Proterozoic, either magmatic or granulite facies zircon as xenocrysts. However, the lower intercept age does not correspond to any known geologic event in the area. We consider it as a mixed age information from a composite zircon population, with no direct geological significance. If this interpretation is correct, the $952 \pm 19$ Ma upper intercept age has no direct geological significance either. It only approximates the crystallization age of the dominant zircon component.

\section{Eclogite facies zircon in an eclogite facies vein}

Zircon separated from the other eclogite facies vein (sample ADNA, Fig. 2f) shows entirely different characteristics. Crystals are large, up to $>1 \mathrm{~mm}$ in size, corresponding to their megacrystic host rock of phe + omp + qtz. Most zircon crystals are colorless and idiomorphic, with simple forms and c/a axis length ratios of $\sim 3$. Quartz inclusions occur. Cathodoluminescence imaging shows chaotic to polygonal zoning, with conspicious bright domains in some crystals (Fig. 7). This pattern is modulated by a weak oscillatory zoning. Indications for inherited cores are missing. The zircons are most probably fluid-precipitated, 'hydrothermal' in origin, and part of the eclogite vein assemblage. This interpretation is supported by the very low ${ }^{208} \mathrm{~Pb} /{ }^{206} \mathrm{~Pb}$ ratios, corresponding to very low $\mathrm{Th} / \mathrm{U}$ ratios in the zircon (model Th/U <0.012; calculated using ${ }^{208} \mathrm{~Pb} /{ }^{206} \mathrm{~Pb}$ and age; Supplementary Table 3). Such low $T h / U$ ratios are characteristic for eclogite facies zircon from the Bergen Arcs (Bingen et al. 2001). They possibly reflect zircon growth in equilibrium with Th-scavenging phases, like epidote-zoisite-group minerals (cf. Bingen et al. 2004), which are present in major amounts in the vein sample. Oscillatory zoning does not counter the interpretation of zircon as hydrothermal in origin. While this zoning is characteristic for magmatic zircon, it has similarly been described for fluid-precipitated zircon, namely from eclogitic veins in the Alps (Rubatto et al. 1999, Rubatto and Hermann 2003). With the exception of one zircon fraction, $\mathrm{U}-\mathrm{Pb}$ data for vein sample ADNA zircon define a cluster of concordant data at $429 \pm 3 \mathrm{Ma}$ (Fig. 6). This is the first set of concordant ID-TIMS data clearly constraining the age of eclogite facies vein precipitation and, consequently, of both eclogite facies fluid infiltration and vein wallrock eclogitization.

\section{Eclogite facies zircon in an amphibolite facies vein}

Zircon from the m-wide amphibolite facies vein of sample HOL4 looks similar to zircon from the eclogite facies vein of sample ADNA (see above), with respect to size, shape, color, and abundance of inclusions. HOL4 zircon proved to be extremely resistant against chemical dissolution. Complete digestion required repeated addition of HF acid, and digestion times up to 3 months. We suspect that this refractiveness is due to an extreme chemical purity of the zircon. $\mathrm{U}$ contents are below $4 \mathrm{ppm}$ and $\mathrm{Pb}$ contents of inclusion-free fractions are lower than $1 \mathrm{ppm}$ (Supplementary Table 5). In addition, the nonradiogenic ${ }^{208} \mathrm{~Pb} /{ }^{204} \mathrm{~Pb}$ (between 38.18 and 38.54, Supplementary Table 5) implies that Th contents are very low ( $<<0.1 \mathrm{ppm})$, and that $\mathrm{Th} / \mathrm{U}$ ratios are close to 0 , as observed similarly in the eclogite facies vein zircon of sample ADNA. The U-Pb isochron age of $427.4 \pm 0.9 \mathrm{Ma}$ (Fig. 6) for zircon from the amphibolite facies vein sample HOL4 is, within limits of error, identical to the U-Pb zircon and $\mathrm{Rb}-\mathrm{Sr}$ multimineral ages for eclogite facies metamorphism in the Lindås nappe. Instead, this particular $\mathrm{U}-\mathrm{Pb}$ age value is significantly different from the $\mathrm{Rb}-\mathrm{Sr}$ mineral isochron age for the 
same sample (414.2 $\pm 4.5 \mathrm{Ma}$, Tab. 1, Fig. 5). Common lead isotopic compositions are a key to explain this discrepancy. The initial ${ }^{206} \mathrm{~Pb} /{ }^{204} \mathrm{~Pb}$ for the zircon population as derived from the isochron data is $18.62 \pm 0.030$, while measured ${ }^{206} \mathrm{~Pb} /{ }^{204} \mathrm{~Pb}$ ratios for feldspar from the same sample and from another nearby amphibolite facies vein are strikingly less radiogenic (16.77 and 16.68, respectively; Supplementary Table 5). We therefore consider the zircon as xenocrysts in the amphibolite facies vein. Most likely they were formed during eclogite facies metamorphism, and later mechanically incorporated into the vein. The zircon $\mathrm{U}-\mathrm{Pb}$ isochron age of $427.4 \pm 0.9 \mathrm{Ma}$ thus gives another hint on the age of eclogite facies fluid infiltration in the Lindås nappe.

\section{$R b-S r$ dating of eclogite facies veins}

Our six unaltered eclogite facies vein and vein-wallrock samples all have yield statistically valid isochron correlations. Validity of the eclogite regressions is verified by MSWD values < 0.81 for all samples (see also Wendt and Carl 1991). This implies that during vein formation all phases crystallized in Sr-isotopic equilibrium. Farther, diffusive isotope redistribution after crystallization of the vein assemblages has been negligible. In a multimineral system, such redistribution would inevitably be inhomogeneous and lead to Sr-isotopic disequilibria, which are not observed. Instead, the minerals of these veins remained as closed systems since crystallization. It has been shown before that initial Sr-isotopic equilibria among all phases of an assemblage, together with absence of a positive correlation between apparent age and grain size for mica, are sufficient criteria to interpret $\mathrm{Rb}-\mathrm{Sr}$ multimineral isochron data from high-grade rocks as crystallization ages (Glodny et al., 2002; Glodny et al., 2005). These criteria are fulfilled here, and we interpret the weighted average age of $429.9 \pm 3.5 \mathrm{Ma}$ as dating eclogite facies fluid activity. Field evidence shows that the fluids channeled in the veins trigger eclogitization of the wallrocks. Therefore, the above age in fact dates eclogitization in the Lindås nappe.

\section{$R b$-Sr data: implications for eclogite facies fluid-rock interaction}

A remarkable observation in the $\mathrm{Rb}-\mathrm{Sr}$ dataset for eclogite facies veins is that the fluidprecipitated vein assemblages generally are in Sr-isotopic equilibrium with their immediate wallrocks. This is evident for example from the sample pair 50-00V (vein) and 50-00E (its wallrock, cf. Tab. 1). The initial $\mathrm{Sr}$ isotopic compositions of these samples are identical within analytical uncertainty. For sample ABJ, megacrystic white mica of the vein is in initial Srisotopic equilibrium with neighbouring eclogitized former granulite (Tab. 1). Isotopic equilibrium between high-pressure veins and host rock has elsewhere been interpreted to indicate local origin of the fluids, from prograde dehydration reactions in vein wallrocks (e.g., Nadeau et al. 1993, Brunsmann et al. 2000, Scambelluri and Philippot 2001 and references therein). However, field evidence in the Lindås nappe shows that here the granulitic assemblages did not generate any internal fluids upon subduction, but only were locally converted to eclogite by infiltration of hydrous fluids from external sources (Fig. 2a; Austrheim 1987, Jamtveit et al. 1990). Isotopic equilibrium between vein minerals and wallrock in the context of external sources for the fluids has implications for the mode of fluid flow. It appears that there was no continuous, long-distance, rapid fluid flow channeled in the veins. In such a situation, fluid advection would likely be associated with advection of Sr from distal sources. This would probably lead to local differences between wallrock $\mathrm{Sr}$ signatures and signatures of vein minerals. Instead, Sr-isotopic equilibrium is much better compatible with a scenario of pulses of brittle hydraulic fracturing (cf. Jamtveit et al. 1990), a process that may be related to subduction seismicity (Austrheim and Boundy 1994, Austrheim et al. 1997, Bjørnerud et al. 2002). This may have been followed by more static, local reactive fluid infiltration into the wallrock, which would easily facilitate isotopic equilibration between fluids and reactive rock. Near-static fluid-wallrock reaction is also consistent with the textures of the veins. Their often megacrystic appearance suggests mineral growth in open, fluid-filled spaces (Fig. 2 d,f). The dominance of quartz and kyanite in many veins reflects the theoretically confirmed high solubility of $\mathrm{Si}$ and $\mathrm{Al}$ in eclogite facies fluids that are in equilibrium with local mafic lithologies (Manning 1998). Eclogitization-related contraction of the wallrock (Jamtveit et al. 1990) sustains open space in the fluid veins and triggers 
additional fluid influx, at a rate controlled by the eclogitization reaction rates. Isotopic equilibration between fluids and rock followed by consumption of the fluid by the eclogitization reactions (Jamtveit et al. 1990) in tandem with only partial eclogitization of the granulites, indicates that the total volume of fluids has been small relative to the rock volume. In line with the conclusions of Jamtveit et al. 1990 and in contrast to the inferences of Camacho et al. 2005, in such a scenario the potential of the fluids to advect heat and matter on a regional scale into the granulite would be minor to negligible.

\section{Summary: the age of eclogitization}

Given the analytical uncertainties, our two zircon U-Pb TIMS ages of $427.4 \pm 0.9$ and $429 \pm 3$ $\mathrm{Ma}$ are indistinguishable from the published $423 \pm 4 \mathrm{Ma}$ age for eclogitization, based on zircon U-Pb SIMS analyses by Bingen et al. (2004). Notably, these U-Pb ages are also identical within error to the Rb-Sr age for eclogite facies veins of $429.9 \pm 3.5 \mathrm{Ma}$ (see above). Boundy et al. (1996) presented a number of ${ }^{40} \mathrm{Ar} /{ }^{39} \mathrm{Ar}$ ages of eclogitic white mica from the Lindås nappe, with age values between $429.2 \pm 0.9$ and $462.6 \pm 0.8 \mathrm{Ma}$. While the older apparent ages were discussed as being biased by excess Ar, a cluster of well-defined plateau ages around $430 \mathrm{Ma}$ was originally interpreted as dating a cooling stage. Recent studies indicate that in absence of recrystallization-inducing processes, eclogite facies white mica may retain its K-Ar system even through eclogite- to UHP conditions and subsequent exhumation (Giorgis et al 2000; Di Vincenzo et al. 2006, and references therein). In the light of this finding, we suggest that the white mica ${ }^{40} \mathrm{Ar} /{ }^{39} \mathrm{Ar}$ age cluster around $430 \mathrm{Ma}(432.6 \pm$ $0.5 \mathrm{Ma} ; 429.2 \pm 0.9 \mathrm{Ma} ; 429.5 \pm 0.6 \mathrm{Ma}$; Boundy et al. 1996) may be re-interpreted. It may in fact directly date crystallization of eclogite facies phengite. Given the consistency of the above age data, we consider a value of $429 \pm 4$ Ma as 'best estimate' for the age of eclogitization in the Lindås nappe. Potential age differences between individual eclogitization events (cf. Bjørnerud et al. 2002) within this time frame cannot be resolved with the currently existing geochronologic tools.

\section{Timing and mode of the amphibolite facies overprint}

\section{$R b$-Sr dating of amphibolite facies metamorphism}

Six out of seven investigated amphibolite facies rocks have yield valid, low-MSWD Rb-Sr multimineral isochron correlations. There is no indication for any post-amphibolite facies intermineral isotope exchange. Two samples of statically amphibolitized former eclogites (samples AB1, Fig. 2c; and sample HUS 1a) showed some textural relics of the eclogitic assemblage, like incompletely reacted garnet. In sample $A B 1$ this is in tandem with slight isotopic disequilibria among low-Rb/Sr phases (MSWD of data regression $=9.4$, Tab. 1). While the high dispersion makes the age of $410.3 \pm 7.9 \mathrm{Ma}$ statistically questionable, it is important to stress that by leaving out some of the low-Rb phases the MSWD decreases, the probability-of-fit increases to $>50 \%$, and above all the calculated ages are indistinguishable from that calculated using all data points. This robustness of the age result despite moderate isotopic disequilibrium encourages us to interpret the age as geologically significant. For the other sample (HUS 1a), the MSWD of 2.3 is statistically still consistent with initial isotopic equilibrium. Rb-Sr isochron age values for all seven investigated rocks, including statically amphibolitized as well as strongly deformed samples, are identical within limits of error. We interpret the weighted mean age of $414.2 \pm 2.8 \mathrm{Ma}$ as best approximation to the crystallization age of amphibolite facies assemblages, and to the age of amphibolite facies deformation. The Sm-Nd mineral isochron age from the statically amphibolitized sample AB1 of $422 \pm 10 \mathrm{Ma}$ (MSWD = 1.2; Fig. 5) is, although imprecise, consistent with the Rb-Sr based age estimate.

\section{Rb-Sr data: implications for amphibolite facies fluid-rock interaction}

The process of amphibolite facies overprint by fluid advection is very similar in its appearance to the process of eclogite facies overprint. Amphibolite facies veins follow brittle fractures, and are accompanied by an amphibolitization aureola in host rock (Fig. 2e). 
Amphibolitization is, in the same way as eclogitization, a fluid-consuming process, not only in granulites but similarly in eclogites (Andersen et al. 1991a,b; Straume and Austrheim 1999). As to the source of the advected fluids, our isotopic data provide no definitive constraints. We observe Sr-isotopic equilibrium at $\sim 414 \mathrm{Ma}$ between feldspar from an amphibolite facies vein, and minerals from the immediate wallrock (sample HU 11b, Tab. 1, Fig. 2e). Field evidence shows that for full amphibolitization, fluid advection was required (Andersen et al. 1991a). It remains unclear whether the observed equilibrated $\mathrm{Sr}$ signature is a mixture of fluid-advected and locally rock-derived $\mathrm{Sr}$, or whether it simply reflects the vein wallrock signature at 414 Ma. Beside advected fluids, also internally generated fluids contributed to amphibolitization reactions in the Lindås nappe. The vast majority of the eclogites shows some degree of arrested, fluid-limited amphibolitization, with formation of disequilibrium textures (e.g. of symplectite around omphacite, Fig. 2d), and without spatial correlation to major fluid pathways. Internal fluid production is caused by characteristic amphibolite facies reactions involving phengite-paragonite breakdown, as described e.g. by Heinrich (1982) and Franz et al. (1986). These reactions are related to decompression and typically occur at $\sim 600^{\circ}, 8-12$ kbar (e.g., Franz et al. 1986) which is confirmed by our thermobarometric data. This type of amphibolite facies symplectite formation is characterized by the same assemblages as the localized amphibolitization related to fluid influx. We conclude that amphibolite facies fluid advection, deformation, and static symplectitic amphibolitization all occurred at similar $P, T$ conditions, and nearly contemporaneous. The age of $414.2 \pm 2.8 \mathrm{Ma}$ dates an episode of significant decompression and exhumation.

\section{Temperature, fluids, metamorphic reactions: what moves $\mathrm{Sr}$ isotopes around?}

As discussed above, assemblages in textural equilibrium show preservation of initial $\mathrm{Sr}$ isotopic equilibrium between all phases. In the Bergen Arcs, this observation holds for both eclogite facies and amphibolite facies assemblages. Preservation of isotopic equilibrium requires absence of any diffusional or reactive $\mathrm{Sr}$ isotope exchange after assemblage crystallization. Statistically valid multimineral $\mathrm{Rb}-\mathrm{Sr}$ isochron correlations therefore date events of full (re)crystallization of an assemblage (cf. Glodny et al. 2005). Temperaturedriven diffusion obviously has not been a major agent of isotope redistribution in the Bergen Arcs. Otherwise, the existence of unaltered, phengite-based $\mathrm{Rb}-\mathrm{Sr}$ age information on the eclogitization event at $\sim 429 \mathrm{Ma}$ side by side (on $\mathrm{cm}$ scale, see Fig. $2 \mathrm{c}$ ) with $\sim 414 \mathrm{Ma}$, similarly phengite-based amphibolitization ages cannot be explained.

Furthermore, published age data on phlogopite in undeformed, ultramafic, granulite facies rocks from the area point to nearly full preservation of biotite isotopic signatures in these granulites through Caledonian metamorphism. Phlogopite-based Grenvillian ages in the range of $\sim 850 \mathrm{Ma}$ have been obtained both from $\mathrm{Rb}-\mathrm{Sr}$ analysis (Kühn et al. 2000) and from ${ }^{40} \mathrm{Ar}-{ }^{39} \mathrm{Ar}$ data (Camacho et al. 2005). This observation is at first hand surprising given the inference that the Lindås nappe experienced temperatures $>600^{\circ} \mathrm{C}$, in a period of at least the $15 \mathrm{Ma}$ between eclogitization and exhumation-related amphibolitization. Preservation of Rb$\mathrm{Sr}$ and $\mathrm{Ar}-\mathrm{Ar}$ signatures is at variance with thermochronological models which assume that thermally driven diffusion is the main mechanism setting 'isotopic clocks'. These models predict $\mathrm{Rb}-\mathrm{Sr}$ and $\mathrm{K}-\mathrm{Ar}$ isotopic resetting both for phlogopite and phengite, in considerably shorter periods and/or at lower temperatures than inferred for the Caledonian history of the Lindås nappe. However, recent studies show that under dry, static conditions classic models of isotopic closure do not apply. Dry, static conditions after crystallization can be inferred for the discussed unaltered granulites and eclogites simply from the unaltered preservation of even delicate granulite- or eclogite facies microstructures (Yardley and Valley 1997; Kühn et al. 2000; Schneider et al. 2006; Raimbourg et al. 2007 and references therein). At such conditions, diffusional $\mathrm{Sr}$ and Ar redistribution is extremely sluggish, so that both $\mathrm{Rb}-\mathrm{Sr}$ and $\mathrm{K}$-Ar signatures of micas can persist through long periods with temperatures far in excess of commonly assumed closure temperatures, as exemplified in the Bergen Arcs and also reported elsewhere (Tilton et al. 1997; Boundy et al. 1997b, Giorgis et al. 2000; Di Vincenzo et al. 2006, Glodny et al. 2007). 
Our $\mathrm{Rb}-\mathrm{Sr}$ isotope data gives another hint on what really moves isotopes around. All attempts at extracting $\mathrm{Rb}-\mathrm{Sr}$ isochron age data from rocks with disequilibrium textures failed because of disequilibrium $\mathrm{Sr}$ isotope distributions. Two examples are presented in Tab. 1 (partially amphibolitized eclogitic veins ADNA and STRO1; MSWD of regression of 37 and 67, respectively; see also Fig. 2 d, f). Because all investigated unretrogressed eclogite facies veins show Sr-isotopic equilibria, the here observed disequilibria most probably are related to the incomplete amphibolitization. We conclude that initial intermineral isotopic equilibrium relationships were either destroyed by fluid-induced recrystallization and isotope transport, or that disequilibria reflect incomplete mixing between rock-derived and isotopically different, fluid-advected Sr. Similar patterns of fluid-induced, arrested retrogression and correlated isotopic disequilibria are well known also from $\mathrm{O}-\mathrm{H}$ isotope and from combined $\mathrm{O}$ isotope/ $\mathrm{Rb}$ Sr studies (Zhang et al. 2003, Chen et al. 2007). It appears that the mobility of trace elements is, as a rule, limited by that of the structure-forming major elements (cf. Villa 1998). Therefore, the preservation of an unretrogressed eclogitic equilibrium assemblage ensures the absence of diffusive perturbation of the isotopic record, and, in turn, textural disequilibria are associated with isotopic disequilibria (see also Villa 2006). This implies that isotopic resetting is commonly achieved by recrystallization inducing processes, in particular by fluiddriven reactions, instead of by temperature-driven diffusion. This opens an elegant way to constrain the mineral reaction history and the tectonometamorphic history of high-grade metamorphic terranes. In the Bergen arc case, granulitization, eclogitization and amphibolitization can be dated side by side using the respective equilibrium assemblages. In combination with metamorphic petrology this yields P-T-t anchorpoints which are unbiased by questionable assumptions on isotope diffusion parameters.

\section{Cold orogenic crust versus warm crust models}

In a recent paper, Camacho et al. (2005) presented Ar-Ar systematics of phlogopite from msized granulite facies ultramafic lenses that are embedded in Lindås nappe eclogites. Phlogopite shows late-Grenvillian Ar-Ar ages around $850 \mathrm{Ma}$, in conjunction with heterogeneous intragrain distribution of excess Ar. Combining these observations with $\mathrm{Ar}$ volume diffusion modelling, the authors put forward a 'non-steady state cold crust model' for the Caledonian thermal and metamorphic evolution of the Lindas nappe. The model proposes coseismic, spasmodic injection of hot $\left(700^{\circ} \mathrm{C}\right)$ fluid into much colder $\left(<400^{\circ} \mathrm{C}\right)$ crust to explain the localized nature of eclogitization. According to this model, eclogite facies temperatures were only reached during heat pulses of $\sim 10$ years duration, and only in the vicinity of fluid filled fractures. Despite a tectonic position at the base of overthickened crust of a collisional orogen, ambient temperatures in the Lindås nappe were modelled to decrease from a maximum between 350 and $400^{\circ} \mathrm{C}$ shortly before eclogitization, to roughly 200 to $150^{\circ} \mathrm{C}$ during exhumation to mid-crustal depths. Cooling from below, by continuously subducting cold crust, has been invoked as a mechanism to avoid thermal equilibration to temperatures above $400^{\circ} \mathrm{C}$.

The model is at variance with several structural characteristics of the Bergen Arcs eclogites (Bjørnerud and Austrheim 2006). It also fails to make the distinction between attainment of eclogite facies P, T conditions and the actual growth of an eclogitic paragenesis, by passing over that metastable preservation of out-of-equilibrium assemblages is the rule whenever water is scarce. Our new geochonologic data, together with field evidence, are similarly at odds with the proposed model. First, incomplete, fluid-limited amphibolitization is ubiquitous, and not confined to the eclogite-rich domains of the Lindås nappe. This shows that the entire massif has been at $\sim 8-10 \mathrm{kbar}, 600^{\circ} \mathrm{C}$ at $\sim 414 \mathrm{Ma}$, and that the granulite facies phlogopite indeed has seen $600^{\circ} \mathrm{C}$ and more in Caledonian times. Second, the partial amphibolitization was decompression-related, and there is no evidence for decompression-related heating. This implies that the eclogites have been at $\sim 600^{\circ} \mathrm{C}$ and more for a prolonged period of time before amphibolitization. Third, a hint to the overall thermal conditions during eclogitization comes from isotopic ages of granitoid dykes occurring particularly in the eastern part of the Lindås nappe. Kühn et al. (2002) dated such dykes, using U-Pb zircon, Sm-Nd and Rb-Sr multimineral isochron data, to between 431.6 \pm 5.1 Ma and 418.2 $\pm 9.2 \mathrm{Ma}$. Granitoid dyke 
formation was interpreted by Kühn et al. (2002) as an effect of subduction-related hydration in the less deeply subducted part of the nappe. This suggests that these dykes are contemporaneous, more 'shallow' equivalents of the eclogite facies veins in the western part of the nappe. Migmatization of granulite facies country rocks close to the granitoid dykes (Kühn et al. 2002), together with coherency of the Lindås nappe during subduction (Jolivet et al 2005) indicates that temperatures of $>600^{\circ} \mathrm{C}$ were reached throughout in the Lindås nappe during the eclogitization process, not only in the eclogitized parts. It follows that most likely a temperature regime with $\mathrm{T}>600^{\circ} \mathrm{C}$ prevailed for $\sim 15 \mathrm{Ma}$, between eclogitization and amphibolitization. Last but not least, the Camacho et al. 2005 model implies strong local thermal gradients during eclogitization, between $700^{\circ} \mathrm{C}$ within fluid-filled fractures and $<400^{\circ} \mathrm{C}$ distal to fluid pathways. This should be reflected in mineralogical gradients, namely in eclogite assemblages $\left(700^{\circ} \mathrm{C}, 15-21 \mathrm{kbar}\right)$ grading into low-T blueschist $\left(<400^{\circ} \mathrm{C}, 15-21\right.$ kbar), as a function of distance to fluid pathways. In the local metabasic rocks such blueschist facies conditions would result in at least local growth of minerals like glaucophane and lawsonite - which have never been described for the Bergen Arcs. Instead, there is evidence for eclogitization with very low reaction progress even in granulites far away from fluid pathways, namely growth of clinozoisite needles in plagioclase, and formation of omphacite + garnet + kyanite reaction rims along contacts between spinel and plagioclase.

It appears that the 'non-steady-state-cold-crust-model' (Camacho et al. 2005) is based on a set of Ar-in-phlogopite diffusion data derived from hydrothermal experiments at pressures much lower than those attained in the Bergen Arcs eclogites. Because preservation of granulitic phases (and Grenvillian isotopic signatures) is clearly related to absence of aqueous fluids, this set of diffusion data is an inappropriate input parameter for diffusion modelling. In addition, hydrothermal experiments are certain to produce incorrectly high 'diffusion' rates, because of the occurrence of dissolution-reprecipitation reactions, mimicking diffusional element mobility (Wood-Walther effect, cf. Villa and Puxeddu 1994). For these reasons, adoption of hydrothermal experiment-derived Ar transport rates for modelling $\mathrm{Ar}$ diffusion in dry granulites at depth is fallacious. As discussed above, predictions and implications of the cold-crust model consequently are at variance with structural, mineralogical and geochronological observations. It does not contribute to a better understanding of the metamorphic evolution of the Bergen Arcs eclogites.

\section{Tectonometamorphic history of the Lindås nappe}

Our data put some new constraints on the tectonometamorphic history of the Lindås nappe, and provide insight into the dynamic evolution of the Caledonian orogen in SW Norway.

The eclogitization age of $429 \pm 4 \mathrm{Ma}$ is consistent with independent estimates on the onset of Caledonian continent-continent collision. First, paleomagnetic data indicate that the previously rapid convergence between Baltica and Laurentia significantly slowed down between 430 and 420 Ma (Torsvik et al. 1996). Second, geochronology of mafic-ophiolitic complexes along the Scandinavian Caledonides indicates a maximum age of $\sim 435 \mathrm{Ma}$ for the onset of continental collision (Andreasson et al. 2003 and references therein). Third, in the foreland of the Caledonides (Jämtland basin), transition from marine to continental sedimentation (cf. Gee 1975) reflects mountain building in the orogen during the Wenlock (428-423 Ma; IUGS 2005), probably as a result of crustal thickening. Convergence between Baltica and Laurentia in the Mid-Silurian has been fairly rapid $(8-10 \mathrm{~cm} / \mathrm{a}$, Torsvik et al. 1996). Crustal thickening and mountain building therefore most likely have been rapid processes as well, confined to a time frame of a few Ma after incipient subduction of continental crust. The initial crustal thickening is thus constrained by the Wenlock sedimentary signal to latest Llandovery times. We conclude that with an eclogitization age of $429 \pm 4 \mathrm{Ma}$, the Bergen Arcs eclogites once formed part of the leading edge of subducted Baltica continental crust. Subduction-related burial proceeded within 1-3 Ma as indicated by plate convergence velocity. Long-term (>1-2 Ma?) 'storage' of the Lindås nappe rocks at mantle depths prior to eclogitization can be ruled out. 
Amphibolitization at $\sim 414 \mathrm{Ma}$ is related to decompression. We adopt the recent basalaccretion-type model for decoupling of the Lindås nappe from the subducting slab and subsequent exhumation to mid-crustal depths by tectonic extrusion (Jolivet et al. 2005). It follows that the eclogites persisted for nearly $15 \mathrm{Ma}(429 \pm 4$ to $414.2 \pm 2.8 \mathrm{Ma})$ at the base of overthickened continental crust, at depths corresponding to $>10$ to $21 \mathrm{kbar}$. This prolonged residence at depth prior to amphibolite facies overprint is in contrast to many recent geochronological datasets for other collision-related high-pressure nappes, for which rapid exhumation immediately after eclogitization has been demonstrated (Rubatto and Hermann 2001, Hacker et al. 2003b, Glodny et al. 2005). Possibly this contrast signifies fundamentally different, yet not understood evolutionary modes of root zones of collisional orogens.

Age data on regional deformation and faulting further constrains the significance of the amphibolitization event in the Lindås nappe. Fossen and Dunlap (1998) presented a group of muscovite and biotite ${ }^{40} \mathrm{Ar} /{ }^{39} \mathrm{Ar}$ ages in the range of $408 \pm 6$ to $415 \pm 2 \mathrm{Ma}$ from regional topto-the-SE shear zones. They interpreted the ages as dating a late stage of SE-directed Caledonian thrusting of the Bergen Arcs nappe pile onto Baltica basement. Coincidence in timing between nappe thrusting and amphibolitization suggests that the amphibolitization relates to an event of tectonic exhumation, in a setting of large-scale orogenic convergence. Final exhumation of the Bergen Arcs eclogites from amphibolite facies to upper crustal levels most likely has been aided by extensional faulting. The age of ductile deformation along major W and NW-dipping extensional shear zones, including the Bergen Arcs shear zone, is given by ${ }^{40} \mathrm{Ar} /{ }^{39} \mathrm{Ar}$ muscovite ages between 402 and $394 \mathrm{Ma}$ (Fossen and Dallmeyer 1998, Fossen and Dunlap 1998).

Summarizing the above results, the tectonometamorphic evolution of the Bergen Arcs eclogites is a prolonged history of subduction, storage at depth, followed by initially syncontractional and later syn-extensional exhumation (Fig. 8). This prolonged history is in marked contrast to the much more rapid subduction-exhumation loop recorded by the tectonostratigraphically lower Western Gneiss Region eclogites. In the Solund-Dalsfjord area, some $50 \mathrm{~km} \mathrm{~N}$ of the Bergen Arcs, granulite facies rocks were eclogitized at $\sim 405 \mathrm{Ma}$, and exhumed to upper crustal depths shortly thereafter, in a time frame of $\sim 5-10 \mathrm{Ma}$ (Hacker et al..2003a; Glodny et al. 2007). Collectively, the data from the Bergen Arcs and the WGR eclogites record a $\sim 30$ Ma history of Caledonian convergence, crustal thickening and attempted subduction of continental crust, prior to extensional orogenic collapse.

\section{Conclusions}

1. $\mathrm{Rb}-\mathrm{Sr}$ multimineral internal isochron data can be used to date separate stages of the metamorphic evolution of high-grade polymetamorphic terrains. For the Lindås nappe, distinction is made between late stages of granulite facies metamorphism at $\sim 850 \mathrm{Ma}$, Caledonian eclogitization at $429.9 \pm 3.5 \mathrm{Ma}$, and an exhumation-related amphibolite facies overprint at $414.2 \pm 2.8 \mathrm{Ma}$.

2. Metamorphic veins are ideally suited for geochronological investigations. This is because vein formation can be related to specific fluid-rock interaction events that control the reaction history of the country rocks. In addition, analysis of vein material circumvents possible problems with isotopic disequilibria due to isotopic inheritance.

3. Eclogite facies veins may contain fluid-precipitated zircon, suitable for U-Pb geochronology. A population of such zircons dates the eclogitization process in the Lindass nappe at $429 \pm 3 \mathrm{Ma}$, consistent with the Rb-Sr data. However, both the observation of Grenvillian zircon in eclogite facies veins and of eclogite facies zircon in amphibolite facies veins shows that presence of xenocrystic zircon in vein assemblages may be a common phenomenon.

4. Intermineral isotopic equilibria for the $\mathrm{Rb}-\mathrm{Sr}$ system are only observed in texturally well equilibrated rocks, i.e., in rocks devoid of textural relics. This finding can be utilized to define PTt anchorpoints for constraining tectonometamorphic evolutions, by direct linkage between petrologically defined PT data for equilibrium assemblages and isotopic ages - 'What you see is what you date'. 
5. Subsequent to eclogitization, the Lindås nappe eclogites resided largely unaltered at the base of Caledonian overthickened crust for $15 \mathrm{Ma}$, at temperatures in excess of $600^{\circ} \mathrm{C}$. Exhumation occurred in two stages, a first stage from eclogite to amphibolite facies conditions $\left(8-10 \mathrm{kbar}, 600^{\circ} \mathrm{C}\right)$ by tectonic extrusion, and a second stage from amphibolite facies to the brittle upper crust, likely by extensional denudation, nearly $30 \mathrm{Ma}$ after initial subduction.

6. Geochronological data from the Lindås nappe confirm that for rocks at dry, static conditions, diffusion parameters often used for thermochronological modelling do not apply. Perfect preservation of initial isotopic equilibrium for 430-Ma eclogite assemblages indicates that intermineral $\mathrm{Sr}$ tracer diffusion has been negligible, despite residence of the rocks for at least $15 \mathrm{Ma}$ at temperatures commonly considered critical for isotopic resetting. Lack of any published ${ }^{40} \mathrm{Ar} /{ }^{39} \mathrm{Ar}$ apparent ages younger than $429 \mathrm{Ma}$ for eclogite facies phases of the Lindås nappe suggests that at dry, static, eclogite facies conditions even Ar in mica phases is virtually immobile. We conclude that recrystallization-inducing processes, like fluid-rock interaction, are the principal agents of isotope redistribution. Instead of temperature-driven diffusion, fluid- induced metamorphic reactions have set isotopic clocks in the Bergen Arcs.

Acknowledgements. We thank J. Herwig, M. Langanke, V. Kuntz, and B. Stöcker (all GFZ Potsdam) for help with sample preparation and photographic work. H. Kemnitz and U. Glenz (GFZ) kindly provided CL images. Fieldwork was supported by GFZ Potsdam and Oslo University. Careful and constructive reviews by I. Villa and B. Bingen are gratefully acknowledged.

\section{References}

Andersen T, Austrheim H, Burke EAJ (1991a) Fluid-induced retrogression of granulites in the Bergen Arcs, Caledonides of W. Norway: fluid inclusion evidence from amphibolite-facies shear zones. Lithos 27:29-42

Andersen T, Austrheim H, Burke EAJ (1991b) Mineral-fluid-melt interactions in high-pressure shear zones in the Bergen Arcs nappe complex, Caledonides of W. Norway: Implications for the fluid regime in Caledonian eclogite-facies metamorphism. Lithos 27:187-204

Andreasson PG, Gee DG, Whitehouse MJ, Schöberg H (2003) Subduction-flip during lapetus Ocean closure and Baltica-Laurentia collision, Scandinavian Caledonides. Terra Nova 15(6):362-369

Austrheim H (1987) Eclogitization of lower crustal granulites by fluid migration through shear zones. Earth Planet Sci Lett 81:221-232

Austrheim H (1990) The granulite-eclogite facies transition: A comparison of experimental work and a natural occurrence in the Bergen Arcs, western Norway. Lithos 25:163-169

Austrheim H (1998) Influence of Fluid and Deformation on Metamorphism of the Deep Crust and Consequences for the Geodynamics of Collision Zones. In: Hacker BR, Liou JG (eds) When continents collide: Geodynamics and geochemistry of Ultrahigh-Pressure Rocks. Kluwer, Dordrecht, pp 297-323

Austrheim H, Griffin WL (1985) Shear deformation and eclogite formation within granulite-facies anorthosites of the Bergen Arcs, Western Norway. Chem Geol 50:267-281

Austrheim H, Mørk MBE (1988) The lower continental crust of the Caledonian mountain chain: evidence from former deep crustal sections in western Norway. Nor Geol Unders Spec Pub 3:102-113

Austrheim H, Boundy TM (1994) Pseudotachylytes generated during seismic faulting and eclogitization of the deep crust. Science 265(5168):82-83

Austrheim H, Råheim A, Krogh TE (1990) Age relationships and petrogenesis of the high-grade metamorphic anorthosite-mangerite-charnockite- suite of the Bergen Arcs, Western Norway. In: Austrheim H (eds) (1990) Fluid induced processes in the lower crust as evidenced by Caledonian eclogitization of Precambrian granulites, Bergen Arcs, Western Norway. PhD thesis, University of Oslo

Austrheim H, Erambert M, Engvik AK (1997) Processing of crust in the root of the Caledonian continental collision zone: The role of eclogitization. Tectonophysics 273:129-153

Becker H, Jochum KP, Carlson RW (1999) Constraints from high-pressure veins in eclogites on the composition of hydrous fluids in subduction zones. Chem Geol 160(4):291-308

Berman RG (1991) Thermobarometry using multiequilibrium calculations: a new technique with petrologic applications. Canadian Mineral 29:833-855 
Bingen B, Davis WJ, Austrheim H (2001) Zircon U-Pb geochronology in the Bergen arc eclogites and their Proterozoic protoliths, and implications for the pre-Scandian evolution of the Caledonides in western Norway. Bull Geol Soc Am 113:640-649

Bingen B, Austrheim H, Whitehouse MJ, Davis WJ (2004) Trace element signature and U-Pb geochronology of eclogite-facies zircon, Bergen arcs, Caledonides of W Norway. Contrib Mineral Petrol 147:671-683

Bjørnerud MG, Austrheim H, Lund MG (2002) Processes leading to eclogitization (densification) of subducted and tectonically buried crust. J Geoph Research 107(B10):14-1 - 14-18

Bjørnerud MG, Austrheim H (2006) Geophysics: Hot fluids or rock in eclogite metamorphism? Nature 440:E4, doi:10.1038/nature04714

Blundy JD, Holland TJB (1990) Calcic amphibole equilibria and a new amphibole-plagioclase geothermometer. Contrib Mineral Petrol 104:208-224

Boundy TM, Essene EJ, Hall CM, Austrheim H, Halliday AN (1996) Rapid exhumation of lower crust durnig continent-continent collision and late extension: Evidence from $40 \mathrm{Ar} / 39 \mathrm{Ar}$ incremental heating of hornblendes and muscovites, Caledonian orogen, western Norway. Bull Geol Soc Am 108:14251437

Boundy TM, Mezger K, Essene EJ (1997a) Temporal and tectonic evolution of the granulite-eclogite association from the Bergen Arcs, western Norway. Lithos 39:159-178

Boundy TM, Hall CM, Li G, Essene EJ, Halliday AN (1997b) Fine-scale isotopic heterogeneities and fluids in the deep crust: ${ }^{40} \mathrm{Ar} /{ }^{39} \mathrm{Ar}$ laser ablation and TEM study of muscovites from a granulite-eclogite transition zone. Earth Planet Sci Lett 148:223-242

Brunsmann A, Franz G, Erzinger J, Landwehr D (2000) Zoisite- and clinozoisite-segregations in metabasites (Tauern Window, Austria) as evidence for high-pressure fluid-rock interaction. J Metamorphic Geol 18:1-21

Burton KW, Kohn MJ, Cohen AS, O'Nions RK (1995) The relative diffusion of Pb, Nd, Sr and O in garnet. Earth Planet Sci Lett 133:199-211

Camacho A, Lee JKW, Hensen BJ, Braun J (2005) Short-lived orogenic cycles and the eclogitization of cold crust by spasmodic hot fluids. Nature 435:1191-1196

Chen JF, Zheng Y-F, Zhao Z-F, Li B, Xie Z, Gong B, Qian H (2007) Relationships between O isotope equilibrium, mineral alteration and $\mathrm{Rb}-\mathrm{Sr}$ chronometric validity in granitoids: implications for determination of cooling rate. Contrib Mineral Petrol 153:251-271

Cohen AS, O'Nions RK, Siegenthaler R, Griffin WL (1988) Chronology of the pressure-temperature history recorded by a granulite terrain. Contrib Mineral Petrol 98:303-311

Di Vincenzo G, Palmeri R (2001) An ${ }^{40} \mathrm{Ar}-{ }^{39} \mathrm{Ar}$ investigation of high-pressure metamorphism and the retrogressive history of mafic eclogites from the Lanterman Range (Antarctica): evidence against a simple temperature control on argon transport in amphibole. Contrib Mineral Petrol 141:15-35

Di Vincenzo G, Tonarini S, Lombardo B, Castelli D, Ottolini L (2006) Comparison of ${ }^{40} \mathrm{Ar}-{ }^{39} \mathrm{Ar}$ and $\mathrm{Rb}-\mathrm{Sr}$ data on phengites from the UHP Brossasco-Isasca Unit (Dora Maira Massif, Italy): Implications for dating white mica. J Petrol 47:1439-1465

Dunning DR, Pedersen RB (1988) U-Pb ages of ophiolites and arc-related plutons of the Norwegian Caledonides: implications for the development of lapetus. Contrib Mineral Petrol 98:13-23

Fossen H (2000) Extensional tectonics in the Caledonides: Synorogenic or postorogenic? Tectonics 19:213-224

Fossen H, Austrheim H (1988) Age of the Krossnes Granite, West Norway. Nor Geol Unders Bull 413:6165

Fossen H, Dallmeyer RD (1998) ${ }^{40} \mathrm{Ar} /{ }^{39} \mathrm{Ar}$ muscovite dates from the nappe region of southwestern Norway: Dating extensional deformation in the Scandinavian Caledonides. Tectonophysics 285:119133

Fossen H, Dunlap WJ (1998) Timing and kinematics of Caledonian thrusting and extensional collapse, southern Norway: evidence from ${ }^{40} \mathrm{Ar} /{ }^{39} \mathrm{Ar}$ thermochronology. J Struct Geol 20:765-781

Franz G, Thomas S, Smith DC (1986) High-pressure phengite decomposition in the Weissenstein eclogite, Münchberger Gneiss Massif, Germany. Contrib Mineral Petrol 92:71-85

Gee DG (1975) A tectonic model for the central part of the Scandinavian Caledonides. Am J Sci 275A:468-515

Giorgis D, Cosca M, Li S (2000) Distribution and significance of extraneous argon in UHP eclogite (Sulu terrain, China): insight from in situ ${ }^{40} \mathrm{Ar} /{ }^{39} \mathrm{Ar}$ UV-laser ablation analysis. EPSL 181:605-615

Glodny J, Bingen B, Austrheim H, Molina JF, Rusin A (2002) Precise eclogitization ages deduced from $\mathrm{Rb} / \mathrm{Sr}$ mineral systematics: The Maksyutov complex, Southern Urals, Russia. Geochim Cosmochim Acta 66:1221-1235

Glodny J, Ring U, Kühn A, Gleissner P, Franz G (2005) Crystallization and very rapid exhumation of the youngest Alpine eclogites (Tauern Window, Eastern Alps) from $\mathrm{Rb} / \mathrm{Sr}$ mineral assemblage analysis. Contrib Mineral Petrol 149:699-712 
Glodny J, Kühn A, Austrheim H (2007) Diffusion versus recrystallization processes in Rb-Sr geochronology: Isotopic relics in eclogite facies rocks, Western Gneiss Region, Norway. Geochim Cosmochim Acta, doi:10.1016/j.gca.2007.10.021 (in press)

Hacker BR, Andersen TB, Root DB, Mehl L, Mattinson JM, Wooden JL (2003a) Exhumation of highpressure rocks beneath the Solund Basin, Western Gneiss Region of Norway. J Metamorph Geol 21:613-629

Hacker BR, Calvert AT, Zhang RY, Ernst WG, Liou JG (2003b) Ultrarapid exhumation of ultrahighpressure diamond-bearing metasedimentary rocks of the Kokchetav Massif, Kazakhstan. Lithos 70:6175

Heinrich CA (1982) Kyanite-eclogite to amphibolite facies evolution of hydrous mafic and pelitic rocks, Adula nappe, Central Alps. Contrib Mineral Petrol 81:30-38

Holland TJB (1980) The reaction albite=jadeite + quartz determined experimentally in the range 600-1200 C. Am Mineral 65:129-134

Holland TJB (1983) The experimental determination of activities in disordered and short-ranges jadeitic pyroxenes. Contrib Mineral Petrol 82:214-220

Holland TJB, Blundy JD (1994) Non-ideal interactions in calcic amphiboles and their bearing on amphibole plagioclase thermometry. Contrib Mineral Petrol 116:433-447

Jamtveit B, Bucher-Nurminen K, Austrheim H (1990) Fluid-controlled eclogitization of granulites in deep crustal shear zones, Bergen Arcs, western Norway. Contrib Mineral Petrol 104:184-193

Jolivet L, Raimbourg H, Labrousse L, Avigad D, Leroy Y, Austrheim H, Andersen T (2005) Softening triggered by eclogitization, the first step toward exhumation during continental subduction. Earth Planet Sci Lett 237:532-547

Kolderup CF, Kolderup NH (1940) Geology of the Bergen Arc System. Bergens Museum Skrifter Nr.20

Krogh EJ (1988) The garnet-clinopyroxene Fe-Mg geothermometer - a reinterpretation of existing experimental data. Contrib Mineral Petrol 99:44-48

Krogh Ravna E (2000) The garnet-clinopyroxene Fe2+-Mg geothermometer: an updated calibration. J Metamorph Geol 18:211-219

Kühn A (2002) The influence of fluid on the granulite to eclogite and amphibolite facies transition: a study in the anorthositic rocks from the Lindås Nappe, Bergen Arcs, West Norway. PhD Thesis, University of Oslo, pp. 1-199

Kühn A, Glodny J, Iden K, Austrheim H (2000) Retention of Precambrian Rb/Sr phlogopite ages through Caledonian eclogite facies metamorphism, Bergen Arc Complex, W-Norway. Lithos 51:305330

Kühn A, Glodny J, Austrheim H, Råheim A (2002) The Caledonian tectono-metamorphic evolution of the Lindås nappe: Constraints from $\mathrm{U} / \mathrm{Pb}, \mathrm{Sm} / \mathrm{Nd}$ and $\mathrm{Rb} / \mathrm{Sr}$ ages of granitoid dykes. Norsk Geologisk Tidsskrift (Nor J Geol) 82:45-57

Kullerud L (1991) On the calculation of isochrons. Chem Geol 87(2):115-124

Ludwig KR (1993) Isoplot- a plotting and regression program for radiogenic isotope data. Version 2.70. U.S.Geological Survey Open-File Report 91-445, 42pp

Ludwig KR (1999) Isoplot/Ex Ver 2.06: A geochronological toolkit for Microsoft Excel. Berkeley Geochronology Center Spec Pub 1a

Manning CE (1998) Fluid composition at the blueschist-eclogite transition in the model system $\mathrm{Na}_{2} \mathrm{O}-$ $\mathrm{MgO}-\mathrm{SiO}_{2}-\mathrm{H}_{2} \mathrm{O}-\mathrm{HCl}$. Schweiz Mineral Petrogr Mitt 78:225-242

Massonne H-J, Schreyer W (1989) Stability field of the high-pressure assemblage talc+phengite and two new phengite barometers. Eur J Mineral 1:391-410

Thöni M, Jagoutz E (1992) Some new aspects of dating eclogites in orogenic belts: Sm-Nd, Rb-Sr, and $\mathrm{Pb}-\mathrm{Pb}$ isotopic results from the Austroalpine Saualpe and Koralpe type-locality (Carinthia/Styria, southeastern Austria) Geochim Cosmochim Acta 56:347-368

Nadeau S, Philippot P, Pineau F (1993) Fluid inclusion and mineral isotopic compositions (H-C-O) in eclogitic rocks as tracers of local fluid migration during high-pressure metamorphism. Earth Planet Sci Lett 114:431-448

Plyusnina LP (1982) Geothermometry and geobarometry of plagioclase-hornblende bearing assemblages. Contrib Mineral Petrol 80:140-146

Powell R (1985) Regression diagnostics and robust regression in geothermometer/geo-barometer calibration: the garnet-clinopyroxene geothermometer revisited. J Metamorphic Geol 3:327-342

Ragnhildstveit J, Helliksen D (1997) Geologisk kart over Norge, Berggrunnskart Bergen, 1:250000. Nor Geol Unders, Bergen

Raimbourg H, Goffé B, Jolivet L (2007) Garnet reequilibration and growth in the eclogite facies and geodynamical evolution near peak metamorphic conditions. Contrib Mineral Petrol 153:1-28

Roberts D, Gee DG (1985) An introduction to the structure of the Scandinavian Caledonides. In: Gee DG, Sturt BA (eds) The Caledonide orogen: Scandinavia and related areas. Wiley, Chichester 
Romer RL, Siegesmund S (2003) Why allanite may swindle about its true age. Contrib Mineral Petrol 146:297-307

Rubatto D, Hermann J (2001) Exhumation as fast as subduction? Geology? Geol Soc Am 29:3-6

Rubatto D, Hermann J (2003) Zircon formation during fluid circulation in eclogites (Monviso, Western Alps): Implications for $\mathrm{Zr}$ and $\mathrm{Hf}$ budget in subduction zones. Geochim Cosmochim Acta 67:2173-2187

Rubatto D, Gebauer D, Compagnoni R (1999) Dating of eclogite-facies zircons: the age of Alpine metamorphism in the Sesia-Lanzo Zone (Western Alps). Earth Planet Sci Lett 167:141-158

Scaillet S (1998) K-Ar (40Ar/39Ar) geochronology of ultrahigh pressure rocks. In: Hacker BR, Liou, JG (eds) When Continents Collide: Geodynamics and geochemistry of ultrahigh-pressure rocks. Kluwer Academic Publishers; Dordrecht, Boston, London 161-201

Scambelluri M, Philippot P (2001) Deep fluids in subduction zones. Lithos 55:213-227

Schneider J, Bosch D, Monié P, Bruguier O (2006) Micro-scale element migration during eclogitization in the Bergen arcs (Norway): A case study on the role of fluids and deformation. Lithos, doi:10.1016/j.lithos.2006.10.001

Spear FS (1980) NaSi <> CaAl exchange equilibrium between plagioclase and amphibole. Contrib Mineral Petrol 72:33-41

Straume AK, Austrheim H (1999) Importance of fracturing during retro-metamorphism of eclogites. J Metamorph Geol 17:637-652

Tilton GR, Ames L, Schertl HP, Schreyer W (1997) Reconaissance isotopic investigations on rocks of an undeformed granite contact within the coesite-bearing unit of the Dora Maira Massif. Lithos 41:25-36

Torsvik TH, Smethurst MA, Meert, JG, Van der Voo R, McKerrow WS, Brasier MD, Sturt BA, Walderhaug HJ (1996) Continental break-up and collision in the Neoproterozoic and Palaeozoic - A tale of Baltica and Laurentia. Earth Sci Rev 40:229-258

Villa IM (1998) Isotopic closure. Terra Nova 10:42-47

Villa IM (2004) Geochronology of metamorphic rocks. Periodico di Mineralogia 73, IGC Firenze Special Issue No. 2, 259-271

Villa IM (2006) From nanometer to megameter: Isotopes, atomic-scale processes, and continent-scale tectonic models. Lithos 87:155-173

Villa IM, Puxeddu M (1994) Geochronology of the Larderello geothermal field: new data and the "closure temperature' issue. Contrib Mineral Petrol 115:415-426

Waters DJ, Martin HN (1993) Geobarometry of phengite-bearing eclogites. Terra Abstracts 5:410-411.

Wendt I, Carl C (1991) The statistical distribution of the mean squared weighted deviation. Chem Geol 86:275-285

Wennberg OP, Milnes AG (1994) Interpretation of kinematic indicatorsalong the northeastern margin of the Bergen Arc system: A preliminary field study. Norsk Geologisk Tidsskrift 74166-173

Widmer T, Thompson AB (2001) Local origin of high pressure vein material in eclogite facies rocks of the Zermatt-Saas Zone, Switzerland. Am J Sci 301:627-656

Yardley BWD, Valley J (1997) The petrologic case for a dry lower crust. J Geoph Research 102(B6):12173-12185

Zhang RY, Liou JG, Zheng YF, Fu B (2003) Transition of UHP eclogites to gneissic rocks of lowamphibolite facies during exhumation: evidence from the Dabie terrane, central China. Lithos 70:269291

\section{APPENDIX: SAMPLE DESCRIPTIONS}

\section{Eclogite facies equilibrium assemblages (veins, and mafic eclogites)}

50-00V (Kvernhusdalen, Holsnøy; UTM ${ }^{2} 83440{ }^{67} 24345$ ) Quartz-rich eclogite facies vein, $2 \mathrm{~cm}$ in diameter, no obvious foliation, in eclogite. Vein has a dm-wide eclogitization aureola. Assemblage: quartz + kyanite (dominant), omphacite, phengite, garnet.

50-00E (Kvernhusdalen, Holsnøy; UTM $\left.{ }^{2} 83440{ }^{67} 24345\right)$ Well-preserved eclogite, finegrained, equigranular, with weak eclogite facies foliation (kyanite preferred orientation), host rock of vein of sample 50-00 V. Assemblage: quartz, omphacite, garnet, kyanite, phengite; amphibolite facies reaction zones along local cracks do not exceed few $\mu \mathrm{m}$ in width.

ABJ (Saltkjel, Radøy, UTM ${ }^{2} 92500{ }^{67} 20800$; Fig. 2c) Eclogite facies vein ( $5 \mathrm{~cm}$ max. diameter) in eclogitic matrix. Assemblage vein: quartz, phengite (some $>2 \mathrm{~cm}$; of variable chemical composition), epidote/clinozoisite, apatite. Assemblage eclogitic wallrock: quartz, 
garnet; omphacite and amphibole in equilibrium (?) intergrowths; biotite (rare), rutile, albite, epidote/clinozoisite quartz, zircon (rounded shapes). Minor amphibolite facies overprint.

78-99 (Husebøvatnet, Holsnøy; UTM ${ }^{2} 81635{ }^{67} 23785$ ) Quartz-kyanite vein, several cm wide, with eclogitization aureola in wallrock. No foliation. Vein and immediate wallrock were used for analysis. Assemblage: quartz, kyanite, omphacite, garnet, apatite, phengite, zircon (very rare). Near-perfect eclogite preservation, apart from a local greenschist facies crack, along which eclogite reacts to fine-grained chlorite-biotite aggregates.

77-99 (Husebøvatnet, Holsnøy; UTM ${ }^{2} 81635{ }^{67} 23785$ ) Quartz-kyanite vein, 1-2 cm wide, with eclogitization aureola in wallrock (Fig. 2b). Vein material is slightly foliated. Vein and immediate wallrock were used for analysis. Assemblage: quartz, kyanite (dominant in the vein), omphacite, garnet, phengite, apatite, traces of magnetite. Near-perfect preservation of eclogite facies equilibrium assemblage.

HUS2 (Saetrevik S-Laget, Holsnøy; UTM ${ }^{2} 83440{ }^{67} 24345$ ) Vein-like felsic mobilisates, in mafic eclogite. Vein assemblage: epidote/clinozoisite, quartz, paragonite, phengite, rutile, albite, apatite. Rock is considered as eclogite facies, because typical phenomena of amphibolite facies retrogression, like biotite growth on white mica, are absent.

\section{Amphibolite facies assemblages (veins, and retrogressed eclogites)}

HUS1a (Saetrevik S-Laget, Holsnøy; UTM ${ }^{2} 83440{ }^{67} 24345$ ) Amphibolite, with some eclogite facies relics. Mineral association: garnet, amphibole, omphacite-symplectite, calcite, white mica, apatite, rutile, titanite, magnetite, quartz, biotite (often in intergrowth with white mica), pyrite.

SJU2 (Sjurdholmen, UTM ${ }^{2} 82080{ }^{67} 26110$ ) Amphibolite facies gneiss, with variable, felsic to mafic bulk composition. Assemblage: quartz, feldspar, biotite, amphibole, epidote/clinozoisite, white mica, pyrite, apatite zircon, rutile (traces). No recognizable eclogite facies relics.

SJU1 (Sjurdholmen, UTM ${ }^{2} 82080{ }^{67} 26110$ ) Quartz-rich, coarse-grained, strongly foliated amphibolite facies gneiss. Assemblage: quartz (statically recrystallized), epidote/zoisite, apatite, white mica of variable chemical composition, biotite, amphibole, feldspar, zircon, pyrite; rutile and garnet are rare.

81-99 (Husebøvatnet, Holsnøy; UTM ${ }^{2} 81635{ }^{67} 23785$ ) Very coarse-grained amphibolite facies vein mineralization. Assemblage: feldspar, quartz, amphibole, white mica, epidote, apatite, chlorite; traces of rutile. Vein has an amphibolitization aureola in wallrock eclogites.

HOL4 (Husebøvatnet, Holsnøy; UTM ${ }^{2} 81630{ }^{67} 23770$ ) Very coarse-grained amphibolite facies vein mineralization. Assemblage: feldspar, quartz, amphibole, white mica, apatite, pyrite, zircon; traces of rutile and garnet. Vein has an amphibolitization aureola in wallrock eclogites.

HU11b (Hundskjeften, Holsnøy; UTM $\left.{ }^{2} 81158{ }^{67} 23925\right)$ Coarse-grained amphibolite, in direct contact to an amphibolite facies vein mineralization. Assemblage: white mica, biotite, epidote, amphibole, feldspar, quartz. Nicely equilibrated rock. Adjacent vein: very coarse-grained vein with feldspar, amphibole, epidote, chlorite, titanite, rutile (rare, idioblastic), zircon (some in intergrowth with rutile), biotite.

AB1 (Saltkjel, Radøy, UTM ${ }^{2} 92500{ }^{67} 20800$ ) Coarse grained amphibolite, formed from eclogite by amphibolite facies fluid infiltration (Fig. 2c). Assemblage: amphibole, plagioclase, apatite, epidote, biotite, titanite, zircon, quartz (rare). Eclogite facies textural relics (reacted garnet, rutile) are rare but suggest that the rock previously has been an eclogite.

\section{Textural and isotopic disequilibria in eclogite facies veins}

STRO1 (Ådnefjell/Holsnøy, UTM $\left.{ }^{2} 84650{ }^{67} 23655\right)$ Eclogite facies vein mineralization, partially affected by amphibolite facies fluids. Vein is rich in idioblastic omphacite crystals that show amphibolite facies reaction rims. Metamorphic reaction is incomplete and starts from grain boundaries and cracks. Mineral association: omphacite-symplectite, amphibole 
(fine-grained), white mica of different chemical compositions, kyanite, zoisite/epidote, pyrite, zircon (rare), quartz, garnet, apatite, biotite (tiny overgrowths on phengite).

ADNA (Ådnefjell/Holsnøy, UTM ${ }^{2} 84650{ }^{67} 23655$ ) Eclogite facies vein mineralization, very coarse-grained. Partial amphibolite facies overprint. Mineral association: Quartz, phengite of variable chem. composition, garnet (with reaction rims), omphacite-symplectite, amphibole (very fine grained), apatite, zoisite-epidote, zircon (rare), apatite, biotite (tiny overgrowths on phengite).

ADN1 (Adnefjell/Holsnøy) Eclogite facies vein, dominated by $\mathrm{cm}$-sized omphacite crystals. Minerals: omphacite, white mica, quartz, apatite, rare garnet. Omphacite shows incipient symplectite formation.

\section{Granulite}

HA693, HA696 (Taulsvågen/Radøy, UTM ${ }^{2} 87132{ }^{67} 30084$ ) Quartz-mangerite, with comparatively very well preserved granulite facies assemblage, (cf. Austrheim 1990). 


\section{TABLES}

Table $1 \mathrm{Rb} / \mathrm{Sr}$ analytical data.

\begin{tabular}{|c|c|c|c|c|c|c|}
\hline $\begin{array}{l}\text { Sample No. } \\
\text { Analysis No. }\end{array}$ & Material & $\mathrm{Rb}[\mathrm{ppm}]$ & Sr $[p p m]$ & ${ }^{87} \mathrm{Rb} /{ }^{86} \mathrm{Sr}$ & ${ }^{87} \mathrm{Sr} /{ }^{86} \mathrm{Sr}$ & $\begin{array}{c}{ }^{87} \mathrm{Sr} /{ }^{86} \mathrm{Sr} 2 \sigma_{\mathrm{m}} \\
{[\%]}\end{array}$ \\
\hline \multicolumn{7}{|c|}{ Eclogite facies equilibrium assemblages (veins, and mafic eclogites) } \\
\hline \multicolumn{7}{|c|}{$50-00 \mathrm{~V}\left(\right.$ vein $\left.; 422 \pm 23 \mathrm{Ma}, \mathrm{MSWD}=0.34, \mathrm{Sr}_{\mathrm{i}}=0.703082 \pm 0.000030\right)$} \\
\hline PS607 & white mica $\mathrm{m}=0.85 \mathrm{~A}$ & 46.5 & 1198 & 0.112 & 0.703749 & 0.0018 \\
\hline PS609 & white mica $>500 \mu \mathrm{m}$ & 45.9 & 1461 & 0.0909 & 0.703630 & 0.0014 \\
\hline PS610 & white mica $\mathrm{nm}=0.93 \mathrm{~A}$ & 44.8 & 1354 & 0.0957 & 0.703670 & 0.0016 \\
\hline PS652 & omphacite & 0.94 & 236 & 0.0115 & 0.703148 & 0.0010 \\
\hline PS653 & garnet & 0.31 & 7.07 & 0.126 & 0.70383 & 0.0068 \\
\hline PS608 & white mica $\mathrm{m}=0.93 \mathrm{~A}$ & 45.8 & 1273 & 0.104 & 0.703702 & 0.0020 \\
\hline \multicolumn{7}{|c|}{ 50-00 E (vein wallrock; $\left.424 \pm 23 \mathrm{Ma}, \mathrm{MSWD}=\mathbf{0 . 8 1}, \mathrm{Sr}_{\mathrm{i}}=0.703052 \pm 0.000030\right)$} \\
\hline PS598 & omphacite & 0.95 & 319 & 0.0086 & 0.703104 & 0.0014 \\
\hline PS604 & white mica $\mathrm{nm}=0.86 \mathrm{~A}$ & 44.7 & 1238 & 0.105 & 0.703668 & 0.0012 \\
\hline PS605 & $\mathrm{wm} \mathrm{m}=0.76,>200 \mu \mathrm{m}$ & 44.1 & 1172 & 0.109 & 0.703721 & 0.0014 \\
\hline PS606 & $w m m=0.86,>200 \mu m$ & 44.5 & 1170 & 0.110 & 0.703717 & 0.0012 \\
\hline \multicolumn{7}{|c|}{ ABJ (vein + wallrock; $\left.431.0 \pm 3.9 \mathrm{Ma}, \mathrm{MSWD}=\mathbf{0 . 6 2}, \mathrm{Sr}_{\mathrm{i}}=0.705157 \pm 0.000018\right)$} \\
\hline PS592 & epidote & 1.84 & 3919 & 0.00136 & 0.705160 & 0.0012 \\
\hline PS591 & apatite & 0.06 & 1679 & 0.00011 & 0.705171 & 0.0014 \\
\hline PS589 & white mica II & 141 & 292 & 1.40 & 0.713761 & 0.0016 \\
\hline PS587 & whole rock & 19.0 & 200 & 0.274 & 0.706823 & 0.0012 \\
\hline PS584 & white mica III & 144 & 491 & 0.847 & 0.710382 & 0.0012 \\
\hline PS580 & white mica I & 147 & 416 & 1.02 & 0.711435 & 0.0012 \\
\hline \multicolumn{7}{|c|}{ 78-99 (vein + wallrock; $\left.426 \pm 17 \mathrm{Ma}, \mathrm{MSWD}=0.69, \mathrm{Sr}_{\mathrm{i}}=0.703006 \pm 0.000021\right)$} \\
\hline PS511 & omphacite & 0.25 & 88.3 & 0.0083 & 0.703065 & 0.0014 \\
\hline PS517 & apatite & 0.60 & 589 & 0.00296 & 0.703016 & 0.0014 \\
\hline PS523 & white mica $\mathrm{m}=2.2 \mathrm{~A}$ & 47.9 & 1297 & 0.107 & 0.703637 & 0.0012 \\
\hline PS525 & white mica $\mathrm{m}=0.8 \mathrm{~A}$ & 47.6 & 1241 & 0.111 & 0.703682 & 0.0014 \\
\hline PS526 & white mica $\mathrm{m}=0.4 \mathrm{~A}$ & 45.4 & 1155 & 0.114 & 0.70370 & 0.0046 \\
\hline PS529 & white mica > $500 \mu \mathrm{m}$ & 47.1 & 1354 & 0.101 & 0.703626 & 0.0014 \\
\hline \multicolumn{7}{|c|}{ 77-99 (vein + wallrock; $\left.426 \pm 21 \mathrm{Ma}, \mathrm{MSWD}=\mathbf{0 . 2 6}, \mathrm{Sr}_{\mathrm{i}}=0.703020 \pm 0.000021\right)$} \\
\hline PS634 & $w m m=0.78-0.83 A$ & 45.4 & 1401 & 0.0937 & 0.703599 & 0.0014 \\
\hline PS628 & $w m=0.66-0.72 \mathrm{~A}$ & 44.0 & 1445 & 0.0880 & 0.703545 & 0.0016 \\
\hline PS627 & omphacite & 0.69 & 318 & 0.00630 & 0.703061 & 0.0014 \\
\hline PS623 & white mica $\mathrm{nm} 0.83 \mathrm{~A}$ & 42.1 & 1304 & 0.0934 & 0.703586 & 0.0016 \\
\hline PS616 & apatite & 1.60 & 608 & 0.00762 & 0.703065 & 0.0014 \\
\hline PS624 & $w m m=0.72-0.78 \mathrm{~A}$ & 38.9 & 1936 & 0.0582 & 0.703369 & 0.0014 \\
\hline \multicolumn{7}{|c|}{ HUS 2 (vein + wallrock; $\left.424 \pm 16 \mathrm{Ma}, \mathrm{MSWD}=\mathbf{0 . 5 6}, \mathrm{Sr}_{\mathrm{i}}=0.704578 \pm 0.000016\right)$} \\
\hline PS508 & zoisite / epidote & 0.28 & 10340 & 0.00008 & 0.704574 & 0.0012 \\
\hline PS515 & apatite & 0.27 & 3259 & 0.00024 & 0.704576 & 0.0014 \\
\hline PS519 & feldspar & 2.22 & 1707 & 0.00375 & 0.704613 & 0.0012 \\
\hline PS527 & white mica $125-200 \mu \mathrm{m}$ & 34.0 & 981 & 0.100 & 0.705173 & 0.0014 \\
\hline PS536 & white mica $\mathrm{nm}=0.5 \mathrm{~A}$ & 30.1 & 1186 & 0.0734 & 0.705015 & 0.0012 \\
\hline PS539 & white mica $\mathrm{m}=0.5 \mathrm{~A}$ & 35.9 & 793 & 0.131 & 0.705381 & 0.0012 \\
\hline \multicolumn{7}{|c|}{ Amphibolite facies assemblages (veins, and retrogressed eclogites/granulites) } \\
\hline \multicolumn{7}{|c|}{ HUS 1a (static retrogression; $\left.410.4 \pm 5.9 \mathrm{Ma}, \mathrm{MSWD}=2.3, \mathrm{Sr}_{\mathrm{i}}=0.704163 \pm 0.000028\right)$} \\
\hline PS586 & omphacite-symplectite & 1.64 & 286 & 0.0166 & 0.704296 & 0.0012 \\
\hline PS594 & amphibole & 2.05 & 245 & 0.0243 & 0.704289 & 0.0016 \\
\hline PS590 & garnet, leached & 0.13 & 33.2 & 0.0114 & 0.704238 & 0.0014 \\
\hline PS579 & $w m>500 \mu m, m=0.34 A$ & 46.8 & 206 & 0.658 & 0.708005 & 0.0014 \\
\hline PS578 & $\mathrm{wm} 200-355 \mu \mathrm{m} \mathrm{nm}=0.34 \mathrm{~A}$ & 46.2 & 220 & 0.606 & 0.707716 & 0.0012 \\
\hline PS577 & $w m$ 200-355 $\mu \mathrm{m} m=0.34 \mathrm{~A}$ & 46.8 & 225 & 0.601 & 0.707647 & 0.0014 \\
\hline PS575 & $\mathrm{wm}>500 \mu \mathrm{m}, \mathrm{nm}=0.34 \mathrm{~A}$ & 46.3 & 206 & 0.650 & 0.707981 & 0.0014 \\
\hline PS588 & apatite & 0.19 & 3222 & 0.00017 & 0.704135 & 0.0012 \\
\hline \multicolumn{7}{|c|}{ SJU2 (gneiss; $415.5 \pm 3.2 \mathrm{Ma}, \mathrm{MSWD}=\mathbf{0 . 4 3}, \mathrm{Sr}_{\mathrm{i}}=0.704750 \pm 0.000019$ ) } \\
\hline PS507 & zoisite / epidote & 2.89 & 1721 & 0.00486 & 0.704778 & 0.0014 \\
\hline PS514 & apatite & 1.36 & 900 & 0.00437 & 0.704777 & 0.0012 \\
\hline PS524 & white mica $>500 \mu \mathrm{m}$ & 117 & 257 & 1.31 & 0.712541 & 0.0012 \\
\hline PS532 & white mica $\mathrm{m}=1.2 \mathrm{~A}$ & 103 & 215 & 1.38 & 0.712974 & 0.0014 \\
\hline PS537 & white mica $\mathrm{m}=0.8 \mathrm{~A}$ & 104 & 214 & 1.40 & 0.712984 & 0.0012 \\
\hline PS535 & biotite & 145 & 7.95 & 54.5 & 1.02689 & 0.0016 \\
\hline
\end{tabular}


Table 1 (continued).

\begin{tabular}{|c|c|c|c|c|c|c|}
\hline $\begin{array}{l}\text { Sample No. } \\
\text { Analysis No. }\end{array}$ & Material & $\mathrm{Rb}[\mathrm{ppm}]$ & Sr [ppm] & ${ }^{87} \mathrm{Rb} /{ }^{86} \mathrm{Sr}$ & ${ }^{87} \mathrm{Sr} /{ }^{86} \mathrm{Sr}$ & $\begin{array}{c}{ }^{87} \mathrm{Sr} /{ }^{86} \mathrm{Sr} 2 \sigma_{\mathrm{m}} \\
{[\%]}\end{array}$ \\
\hline \multicolumn{7}{|c|}{$81-99$ (vein; $\left.418.0 \pm 4.5 \mathrm{Ma}, \mathrm{MSWD}=\mathbf{0 . 3 4}, \mathrm{Sr}_{\mathrm{i}}=0.703349 \pm 0.000018\right)$} \\
\hline PS505 & amphibole & 1.66 & 19.8 & 0.242 & 0.704797 & 0.0014 \\
\hline PS510 & feldspar & 0.10 & 701 & 0.00040 & 0.703359 & 0.0012 \\
\hline PS516 & apatite & 0.17 & 601 & 0.00081 & 0.703343 & 0.0014 \\
\hline PS530 & white mica $\mathrm{m}=0.3 \mathrm{~A}$ & 104 & 257 & 1.17 & 0.710335 & 0.0012 \\
\hline PS531 & white mica $>500 \mu \mathrm{m}$ & 121 & 289 & 1.22 & 0.710573 & 0.0012 \\
\hline PS538** & white mica $\mathrm{m}=0.8 \mathrm{~A}$ & 130 & 293 & 1.29 & 0.709794 & 0.0012 \\
\hline \multicolumn{7}{|c|}{ SJU 1 (gneiss; $408.2 \pm 7.1 \mathrm{Ma}, \mathrm{MSWD}=1.6, \mathrm{Sr}_{\mathrm{i}}=0.704230 \pm 0.000019$ ) } \\
\hline PS509 & zoisite / epidote & 2.11 & 7559 & 0.00081 & 0.704247 & 0.0014 \\
\hline PS518 & apatite & 1.01 & 2018 & 0.00145 & 0.704232 & 0.0016 \\
\hline PS528 & white mica $\mathrm{m}=0.5 \mathrm{~A}$ & 112 & 963 & 0.337 & 0.706220 & 0.0014 \\
\hline PS533 & white mica $>1 \mathrm{~mm}$ & 105 & 1521 & 0.199 & 0.705372 & 0.0016 \\
\hline PS534 & white mica $\mathrm{m}=1.75 \mathrm{~A}$ & 111 & 1014 & 0.317 & 0.706056 & 0.0016 \\
\hline \multicolumn{7}{|c|}{ HOL4 (vein; $\left.414.2 \pm 4.5 \mathrm{Ma}, \mathrm{MSWD}=0.95, \mathrm{Sr}_{\mathrm{i}}=0.703468 \pm 0.000016\right)$} \\
\hline PS297 & white mica $>355 \mu \mathrm{m}$ & 144 & 319 & 1.31 & 0.711150 & 0.0018 \\
\hline PS303 & white mica $>3 \mathrm{~mm}$ & 146 & 344 & 1.23 & 0.710725 & 0.0014 \\
\hline PS328 & apatite & 1.06 & 643 & 0.00476 & 0.703514 & 0.0016 \\
\hline PS867 & feldspar 2 & 0.08 & 754 & 0.00027 & 0.703460 & 0.0018 \\
\hline PS872 & feldspar 1 & 0.07 & 737 & 0.00031 & 0.703461 & 0.0014 \\
\hline \multicolumn{7}{|c|}{ HU 11 b (vein wallrock; $\left.413.4 \pm 5.6 \mathrm{Ma} ; \mathrm{MSWD}=\mathbf{0 . 5 5}, \mathrm{Sr}_{\mathrm{i}}=0.703299 \pm 0.000016\right)$} \\
\hline PS647 & white mica $250-500 \mu \mathrm{m}$ & 46.9 & 705 & 0.192 & 0.704440 & 0.0014 \\
\hline PS648 & white mica $160-250 \mu \mathrm{m}$ & 49.1 & 906 & 0.157 & 0.704203 & 0.0012 \\
\hline PS650 & white mica $>500 \mu \mathrm{m}$ & 42.1 & 681 & 0.179 & 0.704355 & 0.0008 \\
\hline PS646 & biotite & 49.1 & 38.8 & 3.67 & 0.724912 & 0.0012 \\
\hline PS645 & epidote & 7.16 & 4235 & 0.00489 & 0.703325 & 0.0014 \\
\hline PS649 & amphibole & 3.05 & 216 & 0.0407 & 0.703548 & 0.0016 \\
\hline PS610* & feldspar of associated vein & 0.55 & 801 & 0.00197 & 0.703336 & 0.0012 \\
\hline \multicolumn{7}{|c|}{ AB1 (static retrogression; $\left.410.3 \pm 7.9 \mathrm{Ma} ; \mathrm{MSWD}=9.4, \mathrm{Sr}_{\mathrm{i}}=0.704874 \pm 0.000046\right)$} \\
\hline OS76 & whole rock & 6.05 & 1039 & 0.0168 & 0.704996 & 0.0012 \\
\hline OS87 & amphibole & 2.41 & 110 & 0.0636 & 0.705270 & 0.0020 \\
\hline Os90 & plagioclase & 0.22 & 2598 & 0.0003 & 0.704869 & 0.0010 \\
\hline OS89 & apatite & 0.05 & 2424 & 0.0001 & 0.704928 & 0.0024 \\
\hline OS75 & biotite & 134 & 16.8 & 23.5 & 0.842123 & 0.0026 \\
\hline OS91 & epidote & 0.20 & 7043 & 0.0001 & 0.704806 & 0.0026 \\
\hline OS88 & sphene & 0.12 & 339 & 0.0010 & 0.704854 & 0.0014 \\
\hline \multicolumn{7}{|c|}{ Textural and isotopic disequilibria, in eclogite facies veins } \\
\hline \multicolumn{7}{|c|}{ STRO1 $\left(397 \pm 170 \mathrm{Ma}, \mathrm{MSWD}=67, \mathrm{Sr}_{\mathrm{i}}=0.70380 \pm 0.00026\right)$} \\
\hline PS293 & omphacite-symplectite & 0.34 & 33.6 & 0.0297 & 0.704015 & 0.0016 \\
\hline PS373 & omphacite-symplectite & 0.46 & 34.2 & 0.0391 & 0.704110 & 0.0018 \\
\hline PS300 & white mica > $3 \mathrm{~mm}$ & 73.9 & 1134 & 0.189 & 0.704938 & 0.0018 \\
\hline PS327 & apatite & 0.48 & 6710 & 0.00206 & 0.703738 & 0.0014 \\
\hline PS299 & white mica 355-250 Ma & 42.5 & 961 & 0.128 & 0.704369 & 0.0016 \\
\hline \multicolumn{7}{|c|}{ ADN A $\left(483 \pm 90 \mathrm{Ma}, \mathrm{MSWD}=37, \mathrm{Sr}_{\mathrm{i}}=0.70398 \pm 0.00019\right)$} \\
\hline PS288 & white mica $250-355 \mu \mathrm{m}$ & 82.6 & 1062 & 0.225 & 0.705430 & 0.0018 \\
\hline PS357 & omphacite-symplectite & 1.23 & 375 & 0.00953 & 0.704012 & 0.0016 \\
\hline PS356 & apatite & 0.13 & 1132 & 0.00034 & 0.703939 & 0.0016 \\
\hline PS291 & white mica $>0.8 \mathrm{~cm}$ & 86.2 & 1060 & 0.235 & 0.705696 & 0.0018 \\
\hline PS352 & titanite & 2.91 & 4056 & 0.00207 & 0.704082 & 0.0016 \\
\hline
\end{tabular}

Errors are reported at the $2 \sigma$ level. An uncertainty of $\pm 1.5 \%$ is assigned to $\mathrm{Rb} / \mathrm{Sr}$ ratios. rep.: replicate analysis; wm: white mica; wr: whole rock; sz: shear zone; ecl: eclogite; trans.: transition; m/nm: magnetic/nonmagnetic on Frantz magnetic separator, $13^{\circ}$ tilt, at electric current as indicated. $\left(^{*}\right)$ not used for age calculation because mineral separate is from a different sample; $\left(^{* *}\right)$ : considered as outlier, not used for age calculation. 
Figures

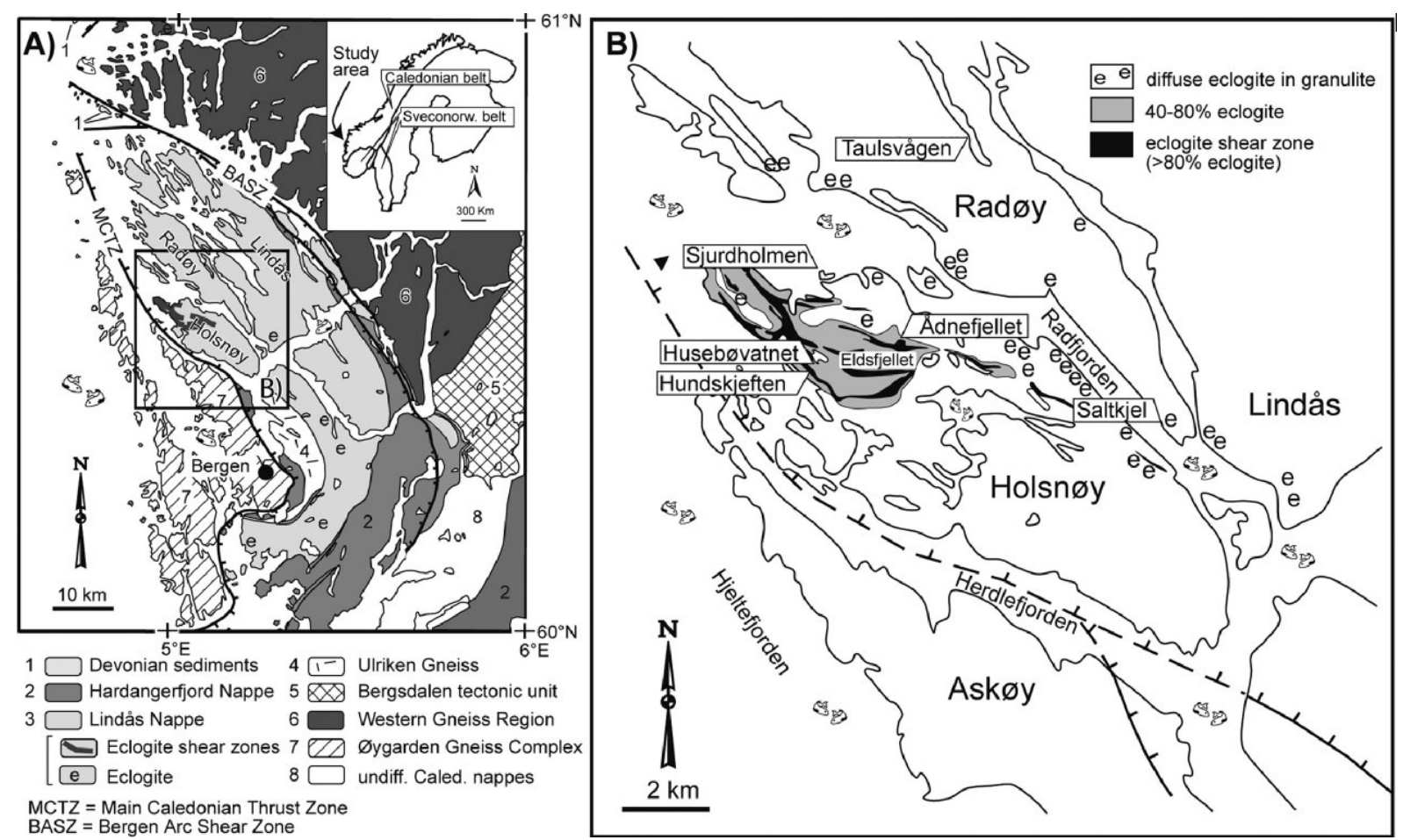

Fig. 1 Sketch map of the study area on and near Holsnøy island, Lindås nappe, Bergen Arcs, W' Norway. 

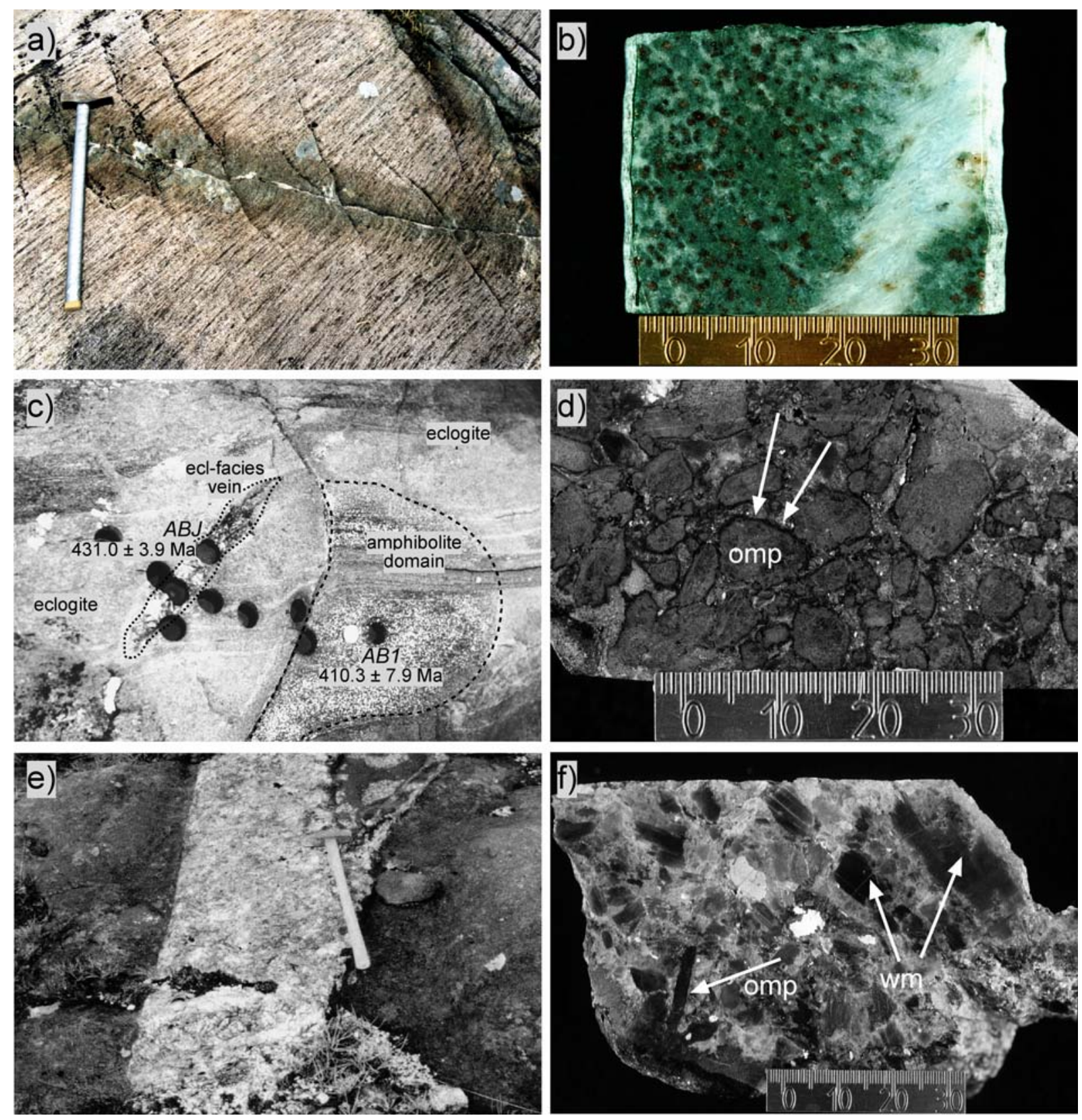

Fig. 2. Field aspects and samples, Lindås nappe, Bergen Arcs. a) Eclogite facies, $1-3 \mathrm{~cm}$ wide vein filled with quartz + kyanite + white mica, with a zone of alteration and deformation in which granulite is transformed to eclogite. Northern Holsnøy. Hammerhead is $15 \mathrm{~cm}$ long. b) Sample 77-99. Vein of quartz +kyanite + white mica in eclogitic matrix. Scale in $\mathrm{mm}$. c) Different episodes of metamorphic fluid-rock interaction. A coarse-grained eclogite facies vein (sample $A B J$ ) is embedded in massive, fine-grained eclogite. An amphibolite facies domain (sample AB1) is delimited by a small fault (center of image) and otherwise diffuse boundaries. It shows massive grain coarsening and an amphibolite facies assemblage with few eclogite facies mineral relics, testifying to local post-eclogite facies fluid infiltration. Drill holes are $4.5 \mathrm{~cm}$ across. Rb-Sr ages are shown. d) Sample ADN1. Eclogite facies vein rich in omphacite crystals. Arrows point to amphibolite facies reaction rims around omphacite. Scale in $\mathrm{mm}$. e) Vein dominated by feldspar + quartz; sample HU10. Note dark reaction rim around the vein in which eclogite is transformed to amphibolite facies assemblages. Sample HU11b is from the wallrock of this vein. Hammerhead is $15 \mathrm{~cm}$ long. f) Sample ADNA. Eclogite facies vein, with $\mathrm{cm}$-sized omphacite and white mica crystals. Scale in $\mathrm{mm}$. 

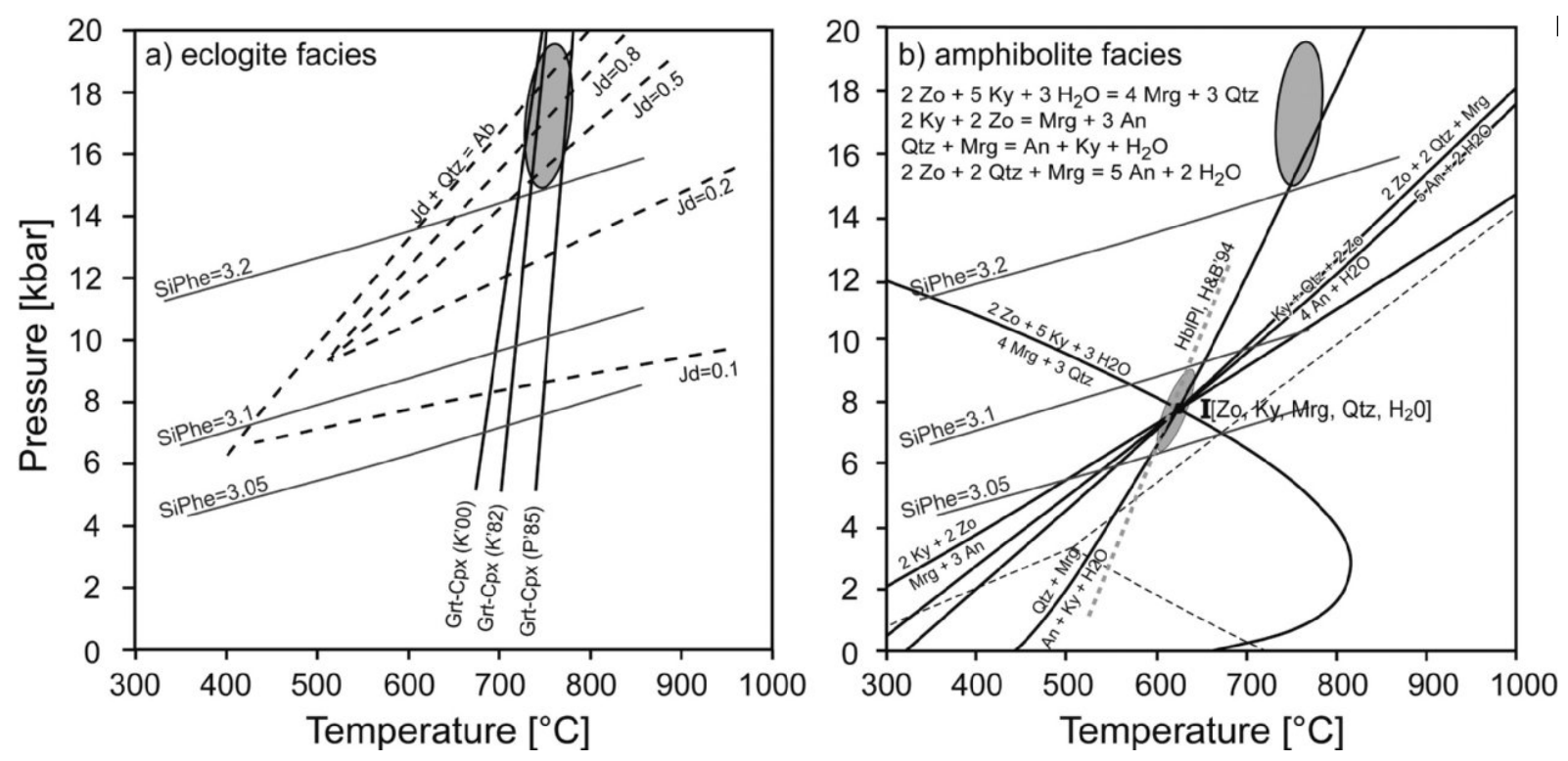

Fig. 3. a) P-T diagram for Holsnøy eclogites. Jadeite (Jd) contours after Holland 1983, Si in phengite (SiPhe) after Massonne \& Schreyer 1989. K00, Krogh-Ravna 2000; K88, Krogh 1988; P85, Powell 1985. b) petrogenetic grid for a portion of the CNASH system, calculated using TWEEQU (Berman 1991) with the dataset Jul92.dat and Ba96.dat. Calculated PT slopes for Si in phengite (Massonne and Schreyer 1989) are included. H\&B'94: Hornblendeplagioclase, after Holland and Blundy 1994. Dark ellipse: eclogite facies conditions for comparison. Dashed lines: $\mathrm{Al}_{2} \mathrm{SiO}_{5}$ phase diagram. 

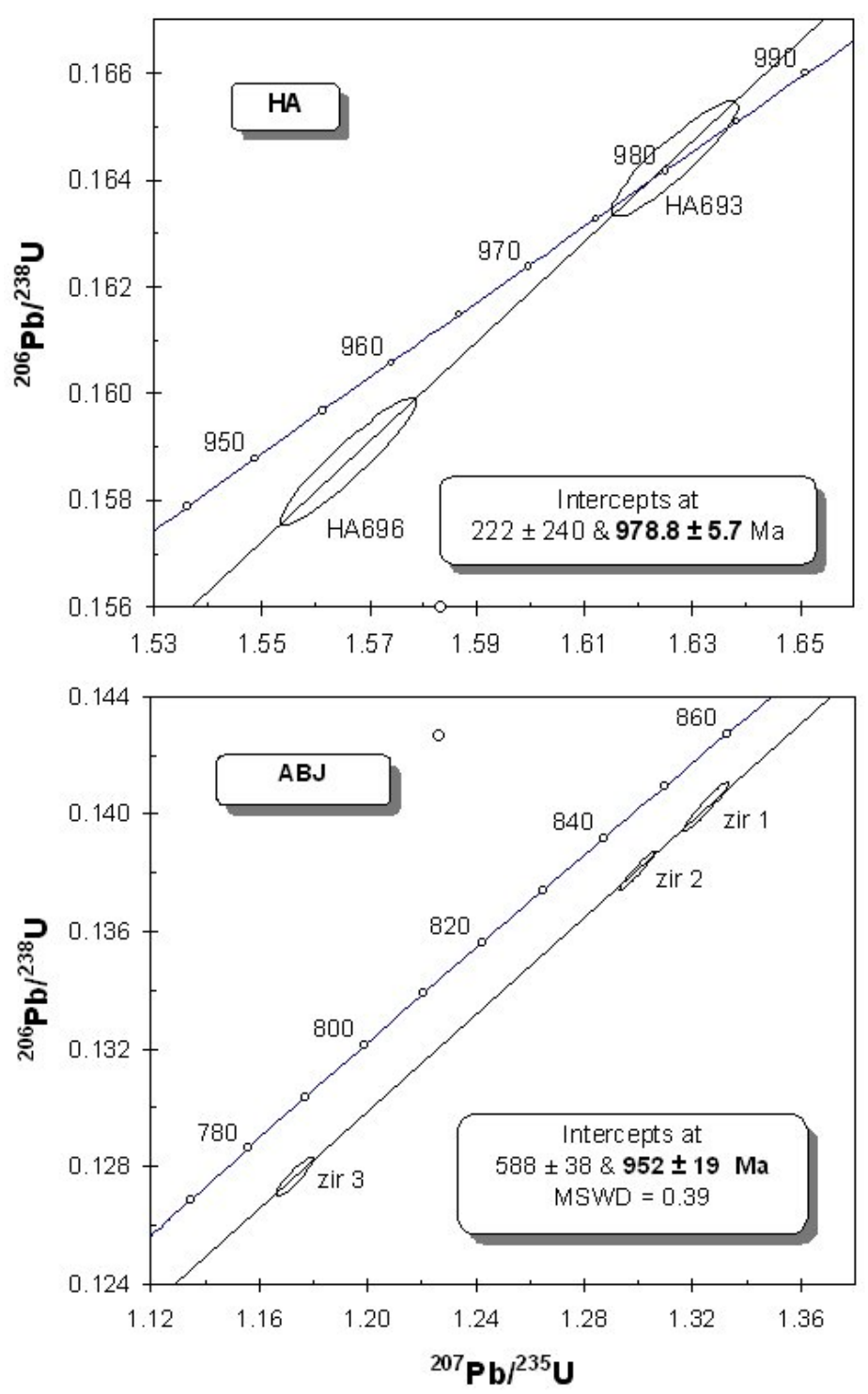

Fig. $4 \mathrm{U}-\mathrm{Pb}$ concordia diagrams for zircon from granulite facies rocks with Caledonian metamorphic overprint, Lindås nappe, Bergen Arcs, Norway. Ellipses around the data points indicate $2 \sigma$ uncertainty. See Supplementary Table 3 for analytical data. 

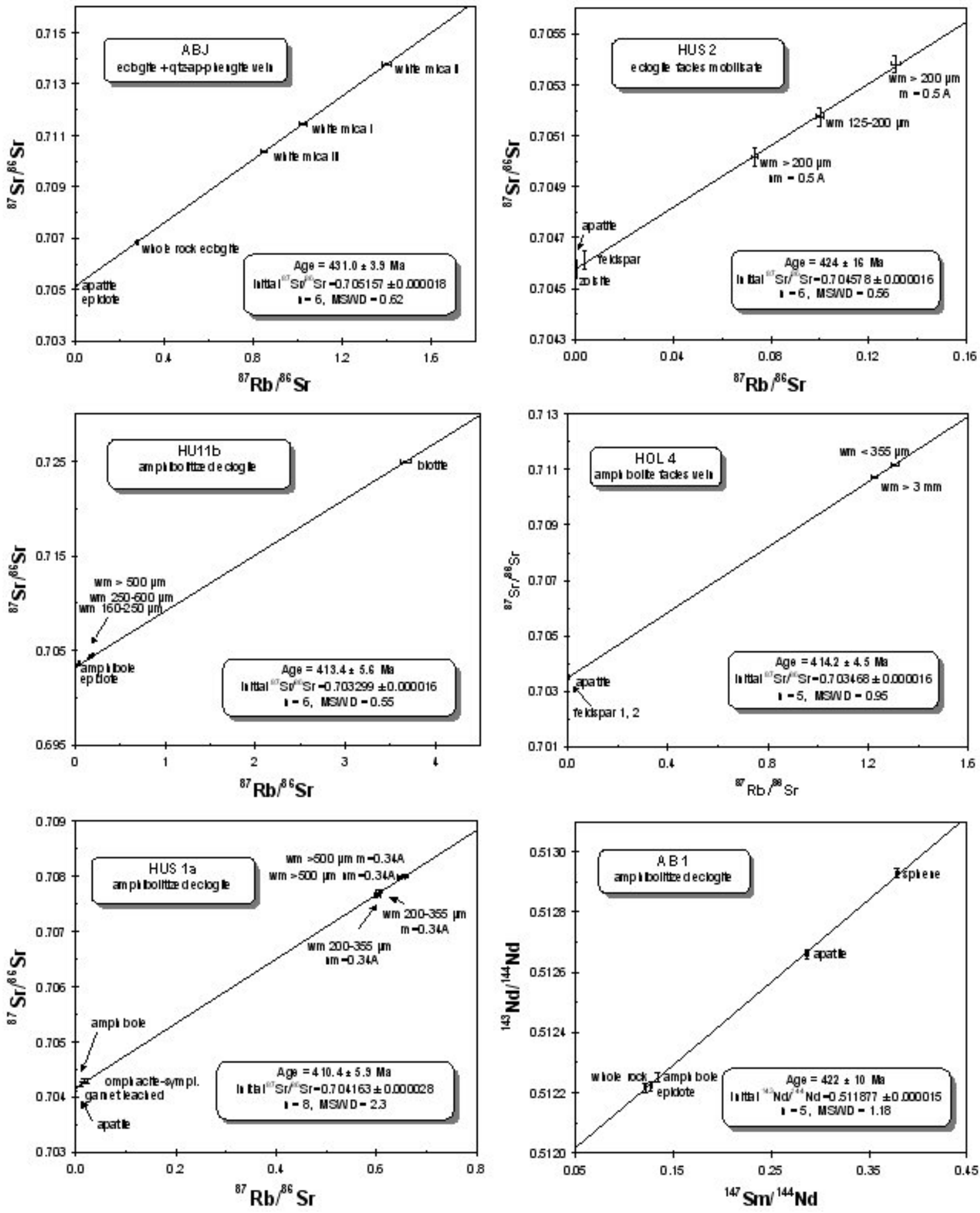

Fig. 5. Rb-Sr and Sm-Nd isotopic data for eclogite facies and amphibolite facies rock, Lindås nappe, Bergen Arcs. Analytical data: see Tab. 1 and Supplementary Table 4. Abbreviations: wm, white mica; bi, biotite; m: magnetic (Frantz separator) at $13^{\circ}$ inclination, and electric current as indicated. 

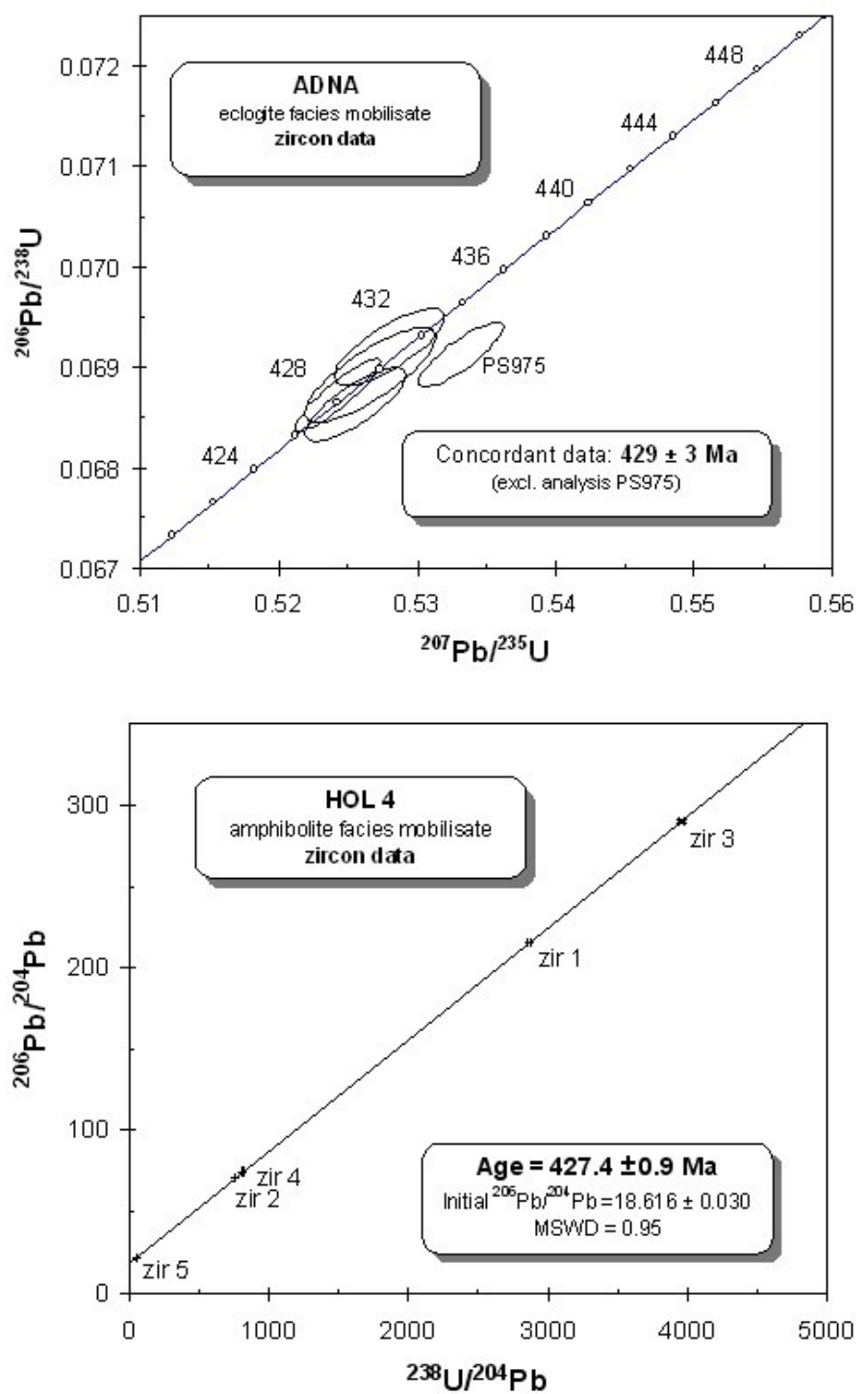

Fig. $6 \mathrm{U}-\mathrm{Pb}$ concordia diagrams for zircon from Caledonian-age veins, Lindas nappe, Bergen Arcs, Norway. Ellipses around the data points indicate $2 \sigma$ uncertainty. See Supplementary Tables 3 and 5 for analytical data. 


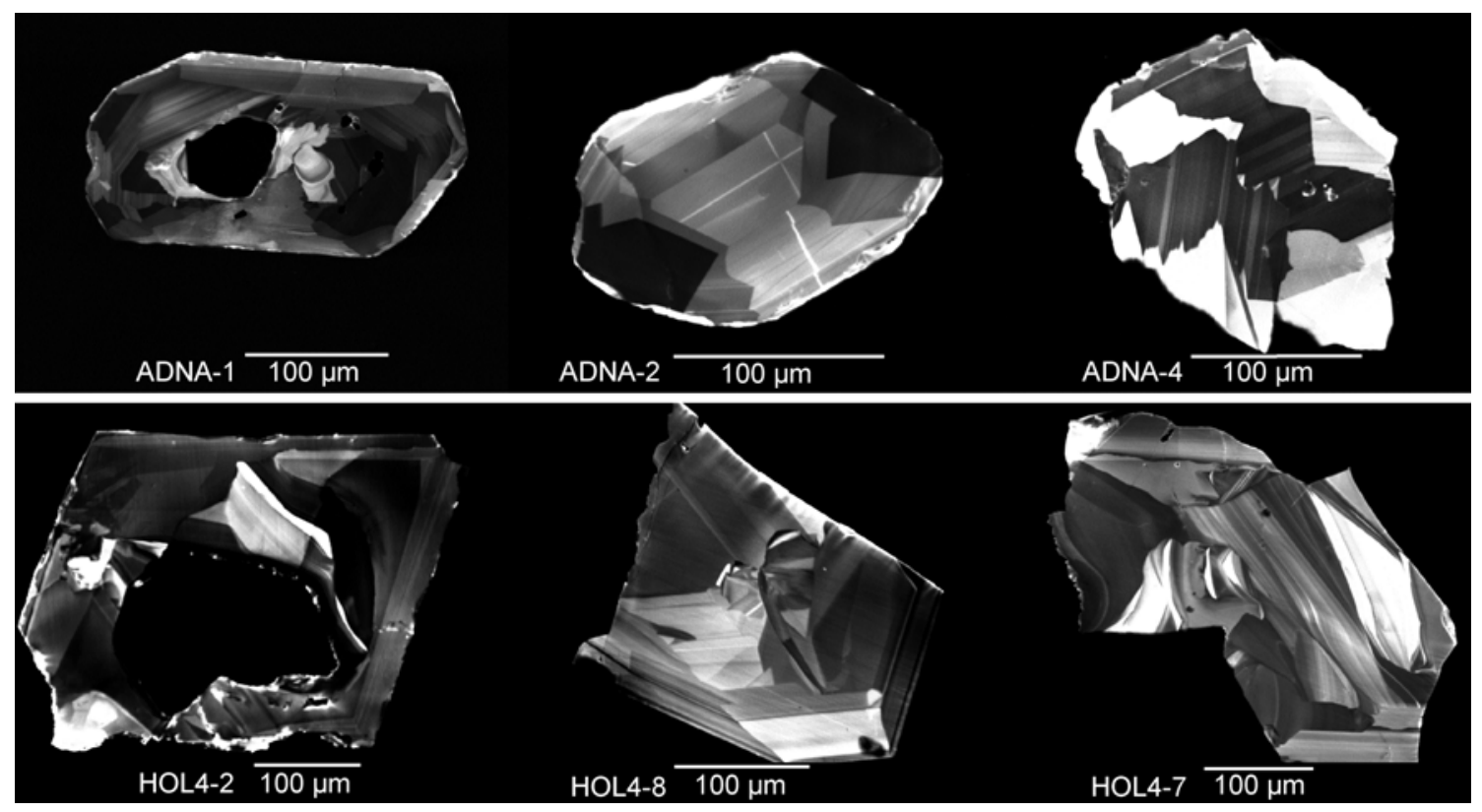

Fig. 7. Cathodoluminescence images of zircon from an eclogite facies vein (sample ADNA) and from an amphibolite facies vein (sample HOL4). Note large inclusions of quartz in zircons ADNA-1 and HOL4-2.

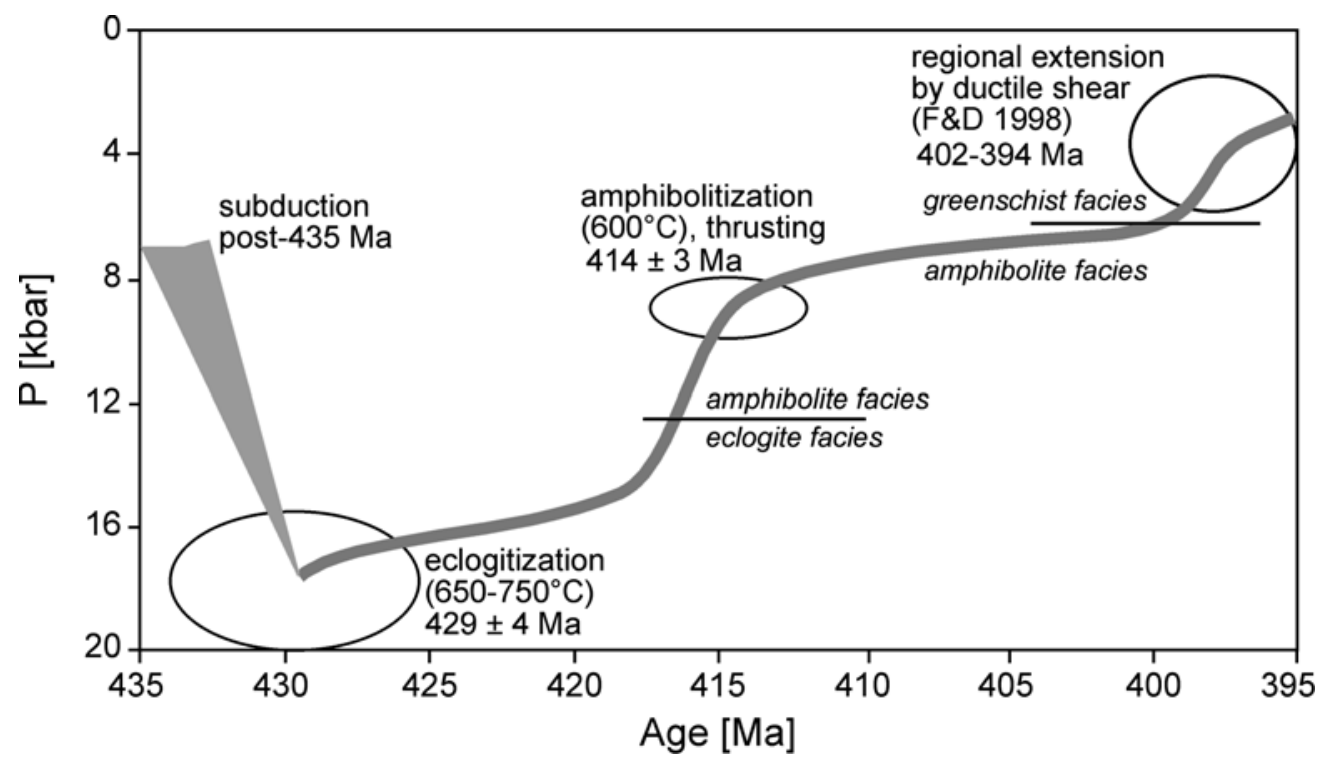

Fig. 8. Schematic Caledonian history of the Lindås nappe. Ellipses represent pressure-time data for fluid-rock interaction and deformation events that are recorded in the rocks. F\&D 1998: Fossen and Dunlap (1998), Fossen and Dallmeyer (1998) 
Electronic Supplementary Material

For

Geochronology of fluid induced eclogite- and amphibolite-facies metamorphic reactions in a subduction-collision system, Bergen Arcs, Norway

By Johannes Glodny, Alexander Kühn, and Håkon Austrheim

Published in

Contributions to Mineralogy and Petrology 
Supplementary Table 1

Representative microprobe analyses of eclogite-

and amphibolite-facies white mica. Normalization to 11 oxygens (anhydrous basis)

\begin{tabular}{|c|c|c|c|c|}
\hline $\begin{array}{l}\text { Sample } \\
\text { Analysis \# } \\
\text { host rock }\end{array}$ & $\begin{array}{c}17 / 00 \\
\text { phe } 7 \\
\text { ecl }\end{array}$ & $\begin{array}{l}17 / 00 \\
\text { phe10 } \\
\text { ecl. - } \\
\text { mob. }\end{array}$ & $\begin{array}{l}77 / 99 \\
\text { phe } 1 \\
\text { amp.- } \\
\text { mob. }\end{array}$ & $\begin{array}{l}77 / 99 \\
\text { phe } 2 \\
\text { amp.- } \\
\text { mob. }\end{array}$ \\
\hline $\mathrm{SiO}_{2}$ & 47.63 & 47.01 & 44.92 & 44.99 \\
\hline $\mathrm{Al}_{2} \mathrm{O}_{3}$ & 32.29 & 31.72 & 35.04 & 34.11 \\
\hline $\mathrm{TiO}_{2}$ & 0.40 & 0.27 & 0.59 & 0.57 \\
\hline $\mathrm{Cr}_{2} \mathrm{O}_{3}$ & 0.00 & 0.00 & 0.00 & 0.00 \\
\hline $\mathrm{MgO}$ & 1.96 & 2.12 & 0.87 & 1.04 \\
\hline $\mathrm{FeO}$ & 1.63 & 2.20 & 1.77 & 1.84 \\
\hline $\mathrm{MnO}$ & 0.06 & 0.01 & 0.11 & 0.03 \\
\hline $\mathrm{CaO}$ & 0.00 & 0.01 & 0.06 & 0.00 \\
\hline $\mathrm{BaO}$ & 0.31 & 0.47 & 0.00 & 0.00 \\
\hline $\mathrm{Na}_{2} \mathrm{O}$ & 1.25 & 0.85 & 1.62 & 1.36 \\
\hline $\mathrm{K}_{2} \mathrm{O}$ & 10.08 & 10.83 & 9.03 & 9.39 \\
\hline $\mathrm{Cl}$ & 0.03 & 0.00 & 0.00 & 0.00 \\
\hline$F$ & 0.00 & 0.03 & n.a. & n.a. \\
\hline total & 95.66 & 95.54 & 94.01 & 93.33 \\
\hline \multirow[t]{2}{*}{$-\mathrm{O}$ eq. $\mathrm{Cl}$} & 0.01 & 0.01 & 0.00 & 0.00 \\
\hline & 95.65 & 95.53 & 94.01 & 93.33 \\
\hline \multicolumn{5}{|c|}{ Structural formulae } \\
\hline $\mathrm{Si}$ & 3.17 & 3.16 & 3.03 & 3.06 \\
\hline $\mathrm{Al}^{\mathrm{IV}}$ & 0.83 & 0.84 & 0.97 & 0.94 \\
\hline $\mathrm{Al}^{\mathrm{VI}}$ & 1.71 & 1.68 & 1.82 & 1.80 \\
\hline $\mathrm{Ti}^{4+}$ & 0.02 & 0.01 & 0.03 & 0.03 \\
\hline $\mathrm{Cr}^{3+}$ & 0.00 & 0.00 & 0.00 & 0.00 \\
\hline $\mathrm{Mg}^{2+}$ & 0.19 & 0.21 & 0.09 & 0.11 \\
\hline $\mathrm{Fe}^{2+}$ & 0.09 & 0.12 & 0.10 & 0.11 \\
\hline $\mathrm{Mn}^{2+}$ & 0.00 & 0.00 & 0.01 & 0.00 \\
\hline $\mathrm{Ca}$ & 0.00 & 0.00 & 0.00 & 0.00 \\
\hline $\mathrm{Ba}$ & 0.01 & 0.01 & 0.00 & 0.00 \\
\hline $\mathrm{Na}$ & 0.16 & 0.11 & 0.21 & 0.18 \\
\hline K & 0.86 & 0.93 & 0.78 & 0.82 \\
\hline $\mathrm{Cl}$ & 0.00 & 0.00 & 0.00 & 0.00 \\
\hline$F$ & 0.00 & 0.01 & n.a. & n.a. \\
\hline total & 7.049 & 7.089 & 7.038 & 7.037 \\
\hline $\mathrm{Mg} / \mathrm{Mg}+\mathrm{Fe}$ & 0.681 & 0.632 & 0.468 & 0.503 \\
\hline $\mathrm{Na} / \mathrm{K}+\mathrm{Na}$ & 0.159 & 0.106 & 0.214 & 0.180 \\
\hline
\end{tabular}

n.a. not analysed. Sample $17 / 00$ is eclogite, cut by an eclogite facies vein, Kvernhusdalen, Holsnøy, equivalent to sample 50-00 (see Appendix for details). Sample $79 / 99$ is the same amphibolite facies vein as sample 81/99, from Husebøvatnet, Holsnøy. 
Supplementary Table 2

P-T estimates for Caledonian-age metamorphic events, Lindås nappe, Bergen Arcs

\begin{tabular}{|c|c|c|c|c|c|}
\hline Reference & Location & facies & $\mathrm{X} \mathrm{H}_{2} \mathrm{O}$ & Temperature & Pressure \\
\hline Austrheim \& Griffin 1985 & N' Holsnøy & ecl & & av. $750^{\circ} \mathrm{C}$ & 16-19 kbar \\
\hline Jamtveit et al. 1990 & N' Holsnøy & ecl & $>0.75$ & $700^{\circ} \mathrm{C}$ & 18-21 kbar \\
\hline Boundy et al. 1997a & N' Holsnøy & ecl & & $670^{\circ} \mathrm{C}$ & $P$ min=15 kbar \\
\hline Mattey et al.1994 & N' Holsnøy & ecl & 0.1 & $700^{\circ} \mathrm{C}$ & $\begin{array}{l}16.9 \text { kbar (ab-jd equilibrium) } \\
17.9 \text { kbar (an-ky-grs-qtz) }\end{array}$ \\
\hline $\begin{array}{l}\text { Kühn et al. } 2002 \\
\text { \& this study }\end{array}$ & N' Holsnøy & ecl & & $\begin{array}{l}650-700^{\circ} \mathrm{C} \text { (grt-phe) } \\
700-750^{\circ} \mathrm{C} \text { (grt-cpx) }\end{array}$ & $\begin{array}{l}P \min =15 \mathrm{kbar}(\mathrm{Jd} \text { in omp }) \\
P \min =15 \mathrm{kbar}(\mathrm{Si} \text { in phe })\end{array}$ \\
\hline $\begin{array}{l}\text { Raimbourg et al. } 2007 \\
\text { Boundy et al. } 1996\end{array}$ & $\begin{array}{l}\text { N' Holsnoy } \\
\text { Holsnøy }\end{array}$ & $\begin{array}{l}\text { ecl } \\
\text { ecl }\end{array}$ & & $\begin{array}{l}720^{\circ} \mathrm{C} \text { (pseudosec.) } \\
\text { ca. } 700^{\circ} \mathrm{C}\end{array}$ & $\begin{array}{l}20.5 \text { kbar (pseudosection) } \\
\text { P min=17 kbar }\end{array}$ \\
\hline Boundy et al. 1996 & Lindås & amph & & $620-690^{\circ} \mathrm{C}$ & $8-12$ kbar \\
\hline Kühn et al. 2002 & Lindås & amph & & $690^{\circ} \mathrm{C}$ (grt-bt) & 9-10 kbar \\
\hline Kühn 2002 & Lindås & amph & & $650-680^{\circ} \mathrm{C}$ (grt-st) & \\
\hline Kühn $2002 \&$ this study & N' Holsnøy & amph & & ca. $600^{\circ} \mathrm{C}$ (hbl-pl) & $\begin{array}{l}>8 \mathrm{kbar}(\mathrm{hbl}-\mathrm{pl}) \\
9.7 \mathrm{kbar}(\mathrm{Si} \text { in phe) } \\
8 \mathrm{kbar}(\mathrm{TWQ} ; \mathrm{zo}, \mathrm{mg}, \mathrm{qtz}, \mathrm{pl})\end{array}$ \\
\hline
\end{tabular}

Ecl, eclogite facies; amph, amphibolite facies; av, average; TWQ, cf. Berman 1991. 
Supplementary Table $3 \mathrm{U}-\mathrm{Pb}$ analytical results

\begin{tabular}{|c|c|c|c|c|c|c|c|c|c|c|c|c|c|c|c|c|c|c|}
\hline \multirow[t]{2}{*}{ Fractions ${ }^{\mathrm{a}}$} & & \multirow{2}{*}{$\begin{array}{l}\text { Weight } \\
(\mathrm{mg})\end{array}$} & \multicolumn{2}{|c|}{ Concentrations } & \multicolumn{2}{|l|}{ Measured } & \multicolumn{7}{|c|}{ Atomic ratios ${ }^{\mathrm{d}}$} & \multicolumn{5}{|c|}{ Apparent ages (Ma) } \\
\hline & & & $\mathrm{U}(\mathrm{ppm})$ & $\begin{array}{l}\mathrm{Pb}_{\text {total }} \\
(\mathrm{ppm})\end{array}$ & $\begin{array}{r}\mathrm{Pb}_{\text {com }}{ }^{\mathrm{b}} \\
(\mathrm{ppm})\end{array}$ & $\begin{array}{l}{ }^{206} \mathrm{~Pb} / \\
{ }^{204} \mathrm{~Pb}^{\mathrm{c}}\end{array}$ & ${ }^{208} \mathrm{~Pb} /{ }^{206} \mathrm{~Pb}$ & ${ }^{206} \mathrm{~Pb} /{ }^{238} \mathrm{U}$ & $\pm 2 \sigma \%$ & ${ }^{207} \mathrm{~Pb}{ }^{235} \mathrm{I}$ & $\mathrm{J} \pm 2 \sigma \%$ & ${ }^{207} \mathrm{~Pb} /{ }^{206} \mathrm{~Pb} \pm$ & $2 \sigma \%$ & ${ }^{206} \mathrm{~Pb} /{ }^{238} \mathrm{U}$ & ${ }^{207} \mathrm{~Pb} /{ }^{235} \mathrm{U}$ & C. Coeff ${ }^{\mathrm{f}}$ & ${ }^{207} \mathrm{~Pb} /{ }^{206} \mathrm{~Pb}$ & $2 \sigma^{\mathrm{c}}$ \\
\hline $\begin{array}{l}\text { Sample } \\
\text { PS875 }\end{array}$ & $\begin{array}{l}A D N A \\
\text { zir } 4 p \text { sp id }\end{array}$ & 0.300 & 152 & 10.8 & 1.19 & 573.0 & 0.0041 & 0.06912 & 0.38 & 0.53313 & 0.47 & 0.05594 & 0.25 & 430.9 & 433.9 & 0.841 & 449.9 & 5.6 \\
\hline PS876 & zir $>3003 p$ fr & 0.297 & 37.3 & 2.79 & 0.46 & 369.7 & 0.0001 & 0.06892 & 0.56 & 0.52664 & 0.73 & 0.05542 & 0.44 & 429.7 & 429.6 & 0.801 & 429.1 & 9.8 \\
\hline PS877 & zir $200-3006 p$ id & id $\quad 0.292$ & 129 & 8.40 & 0.33 & 1685 & 0.0014 & 0.06863 & 0.44 & 0.52557 & 0.57 & 0.05554 & 0.34 & 427.9 & 428.9 & 0.797 & 434.0 & 7.6 \\
\hline PS878 & zir $160-200 \mathrm{id} \mathrm{sp}$ & $\begin{array}{ll}\mathrm{p} & 0.181\end{array}$ & 148 & 11.4 & 2.07 & 328.5 & 0.0027 & 0.06920 & 0.44 & 0.52799 & 0.61 & 0.05534 & 0.39 & 431.4 & 430.5 & 0.768 & 425.8 & 8.8 \\
\hline PS880 & $\begin{array}{l}\text { zir } 3 p \text { sp id }>300 \\
H A\end{array}$ & $\begin{array}{ll}0 & 0.248\end{array}$ & 125 & 8.32 & 0.53 & 1025 & 0.0012 & 0.06872 & 0.43 & 0.52429 & 0.48 & 0.05533 & 0.21 & 428.5 & 428.0 & 0.898 & 425.6 & 4.7 \\
\hline PS194 & $693 \mathrm{zir}>160 \mathrm{pr}$ & 0.396 & 82.5 & 13.9 & 0.10 & 8428 & 0.1122 & 0.16439 & 0.53 & 1.6266 & 0.59 & 0.07176 & 0.25 & 981.1 & 980.6 & 0.909 & 979.3 & 5.0 \\
\hline PS195 & $\begin{array}{l}696 \text { zir }>160 \mathrm{pr} \\
A B J\end{array}$ & 0.493 & 66.1 & 11.2 & 0.17 & 3740 & 0.1456 & 0.15873 & 0.62 & 1.5661 & 0.66 & 0.07156 & 0.23 & 949.7 & 956.9 & 0.939 & 973.4 & 4.7 \\
\hline PS944 & zir1 90-200 cl pf & 0.124 & 62.3 & 10.0 & 0.29 & 1889 & 0.2295 & 0.14025 & 0.48 & 1.3249 & 0.51 & 0.06851 & 0.15 & 846.1 & 856.7 & 0.954 & 884.1 & 3.1 \\
\hline PS949 & zir2 $7 p>250$ xen & 0.282 & 57.1 & 9.01 & 0.30 & 1617 & 0.2165 & 0.13807 & 0.39 & 1.2996 & 0.41 & 0.06826 & 0.11 & 833.7 & 845.5 & 0.963 & 876.6 & 2.3 \\
\hline PS1069 & zir3 $6 p>300$ inc & 0.192 & 75.3 & 11.5 & 0.77 & 779.6 & 0.2320 & 0.12766 & 0.43 & 1.1731 & 0.48 & 0.06665 & 0.20 & 774.5 & 788.1 & 0.910 & 826.8 & 4.1 \\
\hline
\end{tabular}

a Codes in the fraction numbers are zir, zircon. Abbreviations are: 3p, number of crystals or crystal pieces; 30-100 = size fractions ( $\mu$ m); xen, xenomorphic; inc, with inclusions; sp, short prism; pr, prismatic; id,

idiomorphic; fr, fragments; pf, polyfaceted.

${ }^{\mathrm{b}}$ Total common $\mathrm{Pb}$ in sample (initial $\mathrm{Pb}+$ blank).

${ }^{\mathrm{c}}$ Data corrected for fractionation, and common lead in tracer

${ }^{\mathrm{d}}$ Corrected for fractionation, procedural laboratory blanks ( $<25 \mathrm{pg} \mathrm{Pb}, 3 \mathrm{pg} \mathrm{U}$ ), and initial common $\mathrm{Pb}$ (calculated following the model of Stacey and $\mathrm{Kramers}(1975)$. Pb fractionation correction is $0.11 \%$ / amu ( $\pm 0.05 \%$ $2 \sigma) .2 \sigma$ uncertainties on the isotopic ratios are calculated with the error propagation procedure of Ludwig (1980).

${ }_{\mathrm{f}}^{\mathrm{e}} \mathrm{Abs} \mathrm{Pb}^{207} \mathrm{~Pb} /{ }^{235} \mathrm{U} /{ }^{206} \mathrm{~Pb}{ }^{238} \mathrm{U}$ error correlation coefficient 
Supplementary Table 4

$\mathrm{Sm} / \mathrm{Nd}$ analytical data.

\begin{tabular}{|c|c|c|c|c|c|c|}
\hline Sample & Material & Sm [ppm] & $\begin{array}{c}\mathrm{Nd} \\
{[\mathrm{ppm}]}\end{array}$ & ${ }^{147} \mathrm{Sm} /{ }^{144} \mathrm{Nd}$ & ${ }^{143} \mathrm{Nd} /{ }^{144} \mathrm{Nd}$ & $\begin{array}{c}{ }^{143} \mathrm{Nd} /{ }^{144} \mathrm{Nd} \\
2 \sigma_{\mathrm{m}}\end{array}$ \\
\hline \multicolumn{7}{|c|}{ AB1 $\left(422 \pm 10 \mathrm{Ma} ; \mathrm{MSWD}=1.2, \mathrm{Nd}_{\mathrm{i}}=0.511877 \pm 0.000015\right)$} \\
\hline OS76 & whole rock & 17.4 & 87.0 & 0.1216 & 0.512218 & 0.000011 \\
\hline OS87 & amphibole & 1.22 & 5.54 & 0.1343 & 0.512253 & 0.000009 \\
\hline OS88 & sphene & 7.98 & 12.8 & 0.3786 & 0.512928 & 0.000010 \\
\hline PS170 & apatite & 23.2 & 48.9 & 0.2867 & 0.521660 & 0.000007 \\
\hline Os91 & epidote & 102 & 487 & 0.1270 & 0.512220 & 0.000012 \\
\hline
\end{tabular}

Errors are reported at the $2 \sigma$ level. An uncertainty of $\pm 0.5 \%$ is assigned to $\mathrm{Sm} / \mathrm{Nd}$ ratios.

Supplementary Table 5

$\mathrm{U} / \mathrm{Pb}$ isotopic data for sample HOL 4 (zircon, feldspar) and HU10 (feldspar)

\begin{tabular}{lllllllllll}
\hline Sample & material $^{\mathrm{a}}$ & $\begin{array}{l}\text { wt. } \\
{[\mathrm{mg}]}\end{array}$ & $\begin{array}{l}\mathrm{U} \\
{[\mathrm{ppm}]}\end{array}$ & $\begin{array}{l}\mathrm{Pb} \\
{[\mathrm{ppm}]}\end{array}$ & $\begin{array}{l}{ }^{208} \mathrm{~Pb}^{208} \\
\mathrm{~Pb}^{\mathrm{b}}\end{array}$ & $\begin{array}{l}{ }^{238} \mathrm{U} / \\
{ }^{204} \mathrm{~Pb}^{\mathrm{b}}\end{array}$ & $\begin{array}{l}2 \sigma \\
(\%)\end{array}$ & $\begin{array}{l}{ }^{206} \mathrm{~Pb} / \\
\mathrm{Pb}^{\mathrm{b}}\end{array}$ & $\begin{array}{l}2 \sigma \\
(\%)\end{array}$ & $\rho$ \\
\hline PS891 & feldspar HU10 & 11.39 & 0.050 & 2.23 & 36.39 & 1.338 & 0.97 & 16.68 & 0.10 & 0.105 \\
PS1064 & feldspar HOL4 & 1.68 & 0.003 & 3.31 & 36.41 & 0.061 & 17.8 & 16.77 & 0.21 & 0.011 \\
PS892 & zir1 7p y cl sp & 1.76 & 4.66 & 0.397 & 38.49 & 2867 & 0.51 & 215.6 & 0.12 & 0.245 \\
PS893 & zir2 5p cls cl pr & 0.56 & 3.55 & 0.518 & 38.18 & 760.4 & 0.43 & 70.75 & 0.18 & 0.416 \\
PS894 & zir3 4p y sp cl & 1.34 & 4.44 & 0.349 & 38.54 & 3961 & 0.46 & 289.5 & 0.30 & 0.651 \\
PS895 & zir4 fr cr & 0.54 & 4.01 & 0.570 & 38.26 & 813.2 & 0.50 & 74.44 & 0.29 & 0.575 \\
PS848 & zir5 pr cls inc & 0.36 & 4.33 & 5.42 & 38.57 & 53.62 & 0.46 & 22.29 & 0.12 & 0.267 \\
\hline
\end{tabular}

${ }^{a}$ Codes in the fraction numbers are zir, zircon. Abbreviations are: $3 p$, number of crystals or crystal pieces; sp, short prism; fr, fragments; cl, clear; y, yellowish; cls, colorless

${ }^{\mathrm{b}}$ Data corrected for fractionation, and common lead in tracer

$2 \sigma$ uncertainties on the isotopic ratios are calculated with the error propagation procedure of Ludwig (1980).

$\rho$ : error correlation coefficient $\left({ }^{238} \mathrm{U} /{ }^{204} \mathrm{~Pb}-{ }^{206} \mathrm{~Pb} /{ }^{204} \mathrm{~Pb}\right)$

\section{References}

Austrheim H, Griffin WL (1985) Shear deformation and eclogite formation within granulite-facies anorthosites of the Bergen Arcs, Western Norway. Chem Geol 50:267-281

Berman RG (1991) Thermobarometry using multiequilibrium calculations: a new technique with petrologic applications. Canadian Mineral 29:833-855

Boundy TM, Essene EJ, Hall CM, Austrheim H, Halliday AN (1996) Rapid exhumation of lower crust durnig continent-continent collision and late extension: Evidence from $40 \mathrm{Ar} / 39 \mathrm{Ar}$ incremental heating of hornblendes and muscovites, Caledonian orogen, western Norway. Bull Geol Soc Am 108:1425-1437

Boundy TM, Mezger K, Essene EJ (1997a) Temporal and tectonic evolution of the granuliteeclogite association from the Bergen Arcs, western Norway. Lithos 39:159-178

Jamtveit B, Bucher-Nurminen K, Austrheim H (1990) Fluid-controlled eclogitization of granulites in deep crustal shear zones, Bergen Arcs, western Norway. Contrib Mineral Petrol 104:184193

Kühn A (2002) The influence of fluid on the granulite to eclogite and amphibolite facies transition: a study in the anorthositic rocks from the Lindås Nappe, Bergen Arcs, West Norway. PhD Thesis, University of Oslo, pp. 1-199 
Kühn A, Glodny J, Austrheim H, Råheim A (2002) The Caledonian tectono-metamorphic evolution of the Lindås nappe: Constraints from $\mathrm{U} / \mathrm{Pb}, \mathrm{Sm} / \mathrm{Nd}$ and $\mathrm{Rb} / \mathrm{Sr}$ ages of granitoid dykes. Norsk Geologisk Tidsskrift (Nor J Geol) 82:45-57

Ludwig KR (1980) Calculation of uncertainties of U-Pb isotope data. Earth Planet Sci Lett 46:212-220

Mattey D, Jackson DH, Harris NBW, Kelley S (1994) Isotopic constraints on fluid infiltration from an eclogite facies shear zone, Holsnøy, Norway. J Metamorphic Geol 12:311-325

Raimbourg H, Goffé B, Jolivet L (2007) Garnet reequilibration and growth in the eclogite facies and geodynamical evolution near peak metamorphic conditions. Contrib Mineral Petrol 153:1-28

Stacey JS, Kramers JD (1975) Approximation of terrestrial lead isotope evolution by a two-stage model. Earth Planet Sci Lett 26:207-221 